\title{
Manajemen Kepala Sekolah dalam Pemberantasan Buta Aksara Alquran di SMA Nusantara Kota Jambi
}

\author{
Ambo Lang \& Kasful Anwar \\ Program Pascasarjana UIN Sulthan Thaha Saifuddin Jambi
}

\begin{abstract}
Abstrak: Penelitian berfokus pada manajemen Kepala Sekolah dalam pemberantasan buta aksara Alquran di Sekolah Menengah Atas (SMA) Nusantara Kota Jambi. Penelitian menganalisa subyektifitas kepala sekolah sebagai manajer dan obyektifitasnya dalam menjalankan fungsi-fungsi manajemen, serta implementasi fungsi-fungsi manajemen tersebut oleh Guru Pendidikan Agama Islam (PAI) dalam rangka pemberantasan buta aksara Alquran. Informan kunci dalam penelitian ini adalah Kepala Sekolah dan Guru PAI. Informan lainnya adalah Wakil Kepala Sekolah, Guru dan Kepala Tata Usaha. Pengumpulan data dilakukan dengan menggunakan teknik wawancara, observasi, dan dokumentasi. Penelitian menemukan bahwa tipe kepemimpinan yang diterapkan di SMA Nusantara Kota Jambi terdiri dari tipe kepemimpinan demokratis dan situasional dengan menerapkan model manajemen partisipatif. Kepemimpinan demokratis memberi akses yang cukup luas terhadap kebebasan, persamaan, pembagian kekuasaan dan penghargaan terhadap potensi guru PAI, seperti kebebasan dalam mengemukakan pendapat dan dalam mengembangkan inovasi dalam mengajar Alquran. Hal ini dibuktikan misalnya pada aspek pembelajaran Alquran yang dilaksanakan guru PAI dengan mengikuti program yang ada dengan sedikit inovasi guna memberikan pengayaan kemampuan baca Alquran. Penelitian ini juga menemukan bahwa dalam implementasi fungsi-fungsi manajemen, Kepala Sekolah telah menerapkan beberapa fungsi manajemen yang ada seperti planning, organizing, actuating, dan controlling, namun belum memaksimalkan peran evaluating dalam kegiatan manajerial, sehingga ditemukan gambaran pasti yang dapat merefleksikan perkembangan dan kemajuan dari kegiatan pemberantasan buta aksara Alquran di SMA Nusantara Kota Jambi.
\end{abstract}

Kata-kata kunci: manajemen, kepemimpinan, buta aksara Alquran, SMA Nusantara Jambi.

\section{Pendahuluan}

Keterampilan individu dan moral perfomance atau tingkah laku peserta didik merupakan dua hal yang seharusnya diajarkan dan kemudian diimplementasikan dalam kehidupan sehari-hari. Namun demikian, sepertinya aspek moral performance sering sekali hanya dijadikan aspek pendukung dalam pelaksanaan pendidikan di berbagai jenjang. Untuk membentuk karakter peserta didik yang baik berdasarkan nilai-nilai agama dan budaya setempat dibutuhkan sarana yang dapat meningkatkan mentalitas peserta didik, dan dalam kegiatan belajar mengajar pada jenjang pendidikan dasar, menengah dan atas telah dimuat dalam kurikulum yang mencakup muatan lokal. Muatan lokal tersebut umumnya identik dengan pemantapan pemahaman tentang Alquran, tidak terkecuali di Sekolah Menengah Atas Nusantara Kota Jambi. Pemantapan pemahaman tentang Alquran telah beberapa lembaga pendidikan melakukan berbagai kegiatan dalam rangka upaya meningkatkan kompetensi pemahaman peserta didik tentang Alquran. Di antara kegiatan tersebut adalah pemberantasan buta aksara Alquran yang 
dilaksanakan oleh sekolah-sekolah umum, terutama sekolah pada jenjang menengah dan atas. Karena secara teoritis, peserta didik yang telah duduk di sekolah menengah atas pada umunya telah mampu membaca Alquran dengan baik, karena tingkat pemahaman dan daya nalar mereka sudah cukup tinggi, dan diperkuat pula dengan aspek psikologis yang menandakan bahwa mereka telah memiliki tingkat pemikiran yang cukup dewasa dalam berbuat dan menentukan sikap. Namun kenyataannya, masih banyak peserta didik di sekolah-sekolah umum yang masih mengalami buta aksara Alquran, padahal mereka adalah putra-putri dari keluarga dengan tingkat keberagamaan (Islam) yang baik.

Implikasi dari olah pikir, ilmu pengetahuan dan prosedur belajar tersebut di atas terhadap pemberantasan buta aksara Alquran, yang kemudian melahirkan sinergisitas antara ketiga unsur tersebut, dapat dilaksanakan dengan cara belajar membaca Alquran dengan baik. ${ }^{1}$ Belajar membaca Alquran membutuhkan waktu yang cukup untuk dapat memiliki kemampuan baca tulis Alquran. Dan karena keistimewaan Alquran menjadikan pelajaran membaca Alquran itu menempati suatu ilmu tersendiri yang dipelajari secara khusus. Lebih lanjut Zakiah Daradjat mengemukakan bahwa komponen dasar pengajaran Alquran mencakup beberapa hal, ${ }^{2}$ yaitu:

1. Pengenalan huruf hijaiyah, yaitu huruf Arab dari alif sampai dengan ya;

2. Cara membunyikan masing-masing huruf hijaiyah dan sifat-sifat huruf;

3. Bentuk dan fungsi tanda baca, seperti syakal, syaddah, tanda panjang (maad), tanwin dan sebagainya;

4. Bentuk dan fungsi tanda berhenti baca (waqaf), seperti waqaf mutlak, waqaf jawaz dan sebagainya;

5. Cara membaca, melagukan dengan bermacam-macam irama dan bermacammacam qiraat yang dimuat dalam ilmu qiraat dan ilmu nagham;

6. Adabut tilawah, yang berisi tata cara dan etika membaca Alquran sesuai dengan fungsi bacaan itu sebagai ibadah.

Berdasarkan data BPS tahun 2003-2004, posisi kebutaaksaraan penduduk Indonesia usia 10 tahun ke atas sebesar 15.533 .271 orang, terdiri atas perempuan sebanyak 10.643 .823 orang (67\%) dan laki-laki sebanyak 5.042 .338 orang $(32,1$ \%). Pada usia 10-44 tahun sebesar 4.410 .627 orang. Usia 15-44 tahun sebesar 3.986.187 orang. Angka buta aksara tersebut masih akan bertambah, mengingat angka tingkat putus belajar pada kelas-kelas awal (1-3) SD/MI saat ini masih 200.000 s.d. 300.000 per tahun. Khusus di bidang pendidikan, data susenas 2003 menunjukan bahwa penduduk perempuan usia 20 tahun ke atas yang tidak/belum pernah sekolah jumlahnya dua kali lipat penduduk laki-laki 911,56\% berbanding 5,43\%). Penduduk perempuan yang buta aksara sebesar 12,285, sedangkan laki-laki 5,82\% atau dengan kata lain bahwa jumlah buta aksara pada perempuan lebih banyak 2 samapai 3 kali lipat dari laki-laki. ${ }^{3}$

Fenomena nasional tersebut di atas menjadi salah satu perdebatan dialogis keagamaan yang mengacu pada rendahnya kemampuan baca-tulis Alquran bagi anak-anak muslim, sehingga menimbulkan berbagai wacana di

${ }^{1}$ Zakiah Daradjat, Metodik Khusus Pengajaran Agama Islam, (Jakarta: Bumi Aksara, 2008), cet. Ke- 4 , hlm. 89

${ }^{2}$ Ibid., hlm. 91

${ }^{3} \mathrm{http}: / /$ pemberantasan+buta+aksara+al+Qur\%27an\&oq. Diakses tanggal 20 Oktober 2012 
kalangan pemerhati pendidikan Islam. Salah satu wacana negatif yang muncul dalam kaitannya dengan rendahnya kompetensi baca-tulis Alquran anak-anak muslim secara nasional akan berimplikasi pada perilaku negatif yang kemudian bertolak belakang dengan perilaku akhlakul karimah sebagaimana diamanahkan oleh Rasulullah Muhammad Saw melalui hadits-haditsnya.

Problematika kebutaaksaraan baca-tulis Alquran sesungguhnya tidak hanya menjadi persoalan pemerintah pusat, pemerintah provinsi juga mengalami hal yang sama. Tingginya tingkat kebutaaksaraan baca-tulis Alquran di Provinsi Jambi telah menjadi pembahasan menarik, sehingga sering dijadikan tema-tema diskusi dalam berbagai kesempatan pertemuan dalam rangka mencari solusi dan alternatif lain dalam memberantas kebutaaksaraan di Provinsi Jambi. Data faktual yang dapat ditampilkan dalam tulisan ini menunjukkan bahwa buta aksara Alquran mengalami penurunan dari 37.969 siswa menjadi 29.278 siswa dengan rincian siswa SD (semula 34.475 turun menjadi 26.846), SMP (semula 2.594 turun menjadi 1.617), SMA (semula 743 turun menjadi 668) dan SMK (semula 157 turun menjadi 146). Hal ini berdasarkan hasil konfirmasi berdasarkan cross check yang dilakukan oleh UPK di Kabupaten/Kota atas data tersebut. ${ }^{4}$ Oleh sebab itu, dalam rangka pemberantasan buta aksara Alquran, pemerintah provinsi Jambi bersamasama dengan pihak-pihak terkait melakukan berbagai terobosan, termasuk dalam pembuatan kebijakan yang mengarah pada program pemberantasan buta aksara Alquran. Lebih lanjut Drs. H. Idham Kholid, ME dalam sambutan akhir sekaligus membuka workshop secara resmi mengatakan bahwa program pemberantasan buta aksara Alquran merupakan program pembelajaran dalam rangka bebas buta aksara Alquran untuk memenuhi kebutuhan peserta didik atas tambahan pendidikan agama khususnya pendidikan Alquran terutama bagi peserta didik di Sekolah. Bebas buta aksara Alquran dimaksud bertujuan untuk meningkatkan kualitas keimanan dan ketaqwaan bagi peserta didik yang beragama Islam. Misi Program Buta Aksara Alquran (PBAQ) pendidikan Jambi adalah meningkatkan akses layanan prima pendidikan bermutu tanpa diskriminasi; meningkatkan mutu guru yang profesional dan berkarakter; meningkatkan standarisasi dan pengembangan tata kelola sekolah berbasis TIK menuju standar internasional; mengembangkan mutu isi dan proses pembelajaran yang berkarakter dan berjiwa entrepreneur berbasis kearifan lokal. ${ }^{5}$

Pemberantasan buta huruf aksara Alquran dalam wacana Gubernur Jambi, merupakan salah satu program JAMBI EMAS yang dideklarasikan melalui penandatangan Mou pada tanggal 5 Agustus 2012 di sela-sela peringatan Nuzulul Qur'an. ${ }^{6}$ Dalam paparan Gubernur, disampaikan bahwa masih banyak masyarakat Jambi yang buta aksara Alquran. Bagaimana masyarakat tersebut bisa memahami isi kandungan Alquran dan mencintainya jika tidak memiliki kemampuan baca-

\footnotetext{
${ }^{4}$ Ibid.,

${ }^{5}$ http://www.iainjambi.ac.id/index.php/arsip-berita-instititut/728-workshop-programpemberantasan-buta-aksara-alqur\%E2\%80\%99an-2012. Diakses tanggal 1 Maret 2013

${ }^{6}$ Hasan Basri Agus, "Pemberantasan Buta Aksara Alquran", Harian Pagi Tiribun, Agustus 7, 2012, Halaman Utama
} 
tulis Alquran. Lebih lanjut Gubernur menjelaskan, sangatlah tepat kebijakan yang dikemukakan oleh pemerintah Jambi dalam memerangi buta aksara Alquran. ${ }^{7}$

Keresahan yang sesungguhnya menjadi problematika serius dalam masyarakat adalah bagaimana lembag-lembaga pendidikan yang ada di Provinsi Jambi dapat melakukan real act dalam pemberantasan buta aksara Alquran, khususnya Sekolah Menengah Atas Nusantara kota Jambi. Dengan adanya sejumlah siswa yang belum mampu membaca Alquran di sekolah tersebut menjadi persoalan tersendiri bagi seluruh elemen sekolah tersebut, terutama dalam mengimplementasikan program Pemerintah Provinsi Jambi yang berkenaan dengan pemberantasan buta aksara Alquran.

Dengan demikian, maka salah satu upaya konkrit dalam pemberantasan buta aksara Alquran adalah dengan mengajarkan Alquran di sekolah-sekolah yang terintegrasi dalam kegiatan proses belajar mengajar di sekolah. Dalam kondisi ini, kepala sekolah sebagai top leader mempunyai peranan penting dalam menumbuhkembangkan kegiatan belajar mengajar Alquran dalam rangka pemberantasan buta aksara Alquran. Kompetensi manajemen kepala sekolah dalam penataan administrasi belajar mengajar Alquran dengan memaksimalkan peran guru, merupakan salah satu upaya positif dalam pemberantasan buta aksara Alquran.

Kepala sekolah sebagai pimpinan tertinggi dalam sebuah lembaga pendidikan memiliki tanggung jawab yang cukup berat dalam mensukseskan program sekolah. Meskipun dalam praktiknya, ia berperan sebagai pengarah, dan pemberi instruksi, namun pada prinsipnya ia bertanggung jawab terhadap pengelolaan administrasi persekolahan secara keseluruhan. Dengan demikian, maka kepala sekolah merupakan central act dalam seluruh aktivitas sekolah, dimana kebijakannya sangat berpengaruh dalam pelaksanaan program sekolah. Kebijakan dalam hal ini adalah alat untuk mencapai tujuan yang mencakup pedoman, peraturan, dan prosedur yang dibuat untuk mendukung usaha mencapai tujuan yang telah ditetapkan, termasuk dalam pengambilan keputusan dan untuk memberi jawaban atas situasi yang rutin dan berulang. ${ }^{8}$

Berdasarkan hal tersebut di atas, maka praktik manajerial yang sesuai dengan prinsip-prinsip manajemen akan memberikan kontribusi positif dalam memajukan dan mengembangkan sebuah lembaga pendidikan dalam pemberantasan buta aksara Alquran. Karena memang secara fakta, input dari berbagai lembaga pendidikan yang afiliasinya sekolah umum terdapat banyak peserta didik yang tidak memiliki kompetensi baca-tulis Alquran dengan baik.

Sekolah Menengah Atas Nusantara merupakan salah satu lembaga pendidikan formal yang terdapat di kota Jambi, lembaga pendidikan ini berstatus swasta di bawah naungan Yayasan Pendidikan Nusantara (YPN) kota Jambi. Melihat tingginya animo masyarakat kota Jambi terhadap pendidikan, terutama para orang tua yang memiliki perhatian serius terhadap kelangsungan pendidikan putra-putri mereka guna mempersiapkan mereka untuk dapat bersaing dalam dunia global, maka beberapa tokoh masyarakat yang tergabung dalam Yayasan

${ }^{7}$ http://infojambi.com/ij/depan/pariwara/2200-penandatanganan-mou-pemberantasanbuta-aksara-al-qur\%E2\%80\%99an.html

8 Fred R. David, Terj., Manajemen Strategis: Konsep, (Jakarta: Salemba Empatm 2006), hlm. 17 
Pendidikan Nusantara (YPN) merumuskan beberapa langkah dalam rangka pendirian sebuah lembaga pendidikan yang dapat menampung aspirasi masyarakat terhadap kelangsungan pendidikan putra-putri mereka.

Kemajuan dan perkembangan ilmu pengetahuan dan teknologi yang begitu pesat telah membawa perubahan di hampir semua aspek kehidupan, dimana berbagai permasalahan hanya dapat dipecahkan dengan upaya penguasaan dan peningkatan ilmu pengetahuan dan teknologi. Selain bermanfaat bagi kehidupan manusia disatu sisi perubahan tersebut juga telah membawa manusia ke dalam persaingan global yang semakin ketat yang membutuhkan kesiapan seluruh elemen pendidikan agar dapat bersaing dalam dunia pendidikan yang lebih terbuka dan kompetetif. Agar mampu berperan dalam persaingan global, maka sebagai bangsa kita perlu terus mengembangkan dan meningkatkan kualitas sumber daya manusia (human resources).

Menyikapi pertumbuhan dan perkembangan ilmu pengetahuan dan teknologi guna mewujudkan sebuah lembaga pendidikan yang kompetetif, Sekolah Menengah Atas Nusantara kota Jambi melakukan berbagai langkah-langkah progressif dan terobosan yang dapat mensejajarkan sekolah tersebut dengan sekolah-sekolah negeri yang selama ini menjadi impian peserta didik. Upaya-upaya yang dilakukan seluruh civitas akademik Sekolah Menengah Atas Nusantara kota Jambi membuahkan hasil yang cukup menggembirkan, dimana sekolah ini telah mendapat pengakuan dari beberapa pihak tentang kuantitas dan kualitas pendidikannya. Salah satu indikator yang menjadi alat ukur keberhasilan tersebut adalah bahwa Sekolah Menengah Atas Nusantara kota Jambi mendapat pengakuan sebagai salah satu sekolah favorit dan sekolah unggulan di kota Jambi. ${ }^{9}$ Standar pengukuran tersebut mengacu pada kesungguhan Sekolah Menengah Atas Nusantara kota Jambi dalam menerapkan disiplin yang sangat baik bagi siswasiswinya. Di samping itu juga, dalam proses belajar mengajar, sekolah ini telah menerapkan Kurikulum Tingkat Satuan Pendidikan (KTSP) yang kemudian disempurnakan dengan Kurikulum Berbasis Kompetensi (KBK).

Sebagai bukti otentik atas kesungguhan seluruh komponen Sekolah Menengah Atas Nusantara kota Jambi, khususnya kepala sekolah dalam memajukan lembaga yang dipimpinnya tersebut, seluruh komponen sekolah bersama dengan kepala sekolah bekerja keras sesuai dengan peran masing-masing dan bekerjasama dengan stakeholder yang ada, terutama dalam kaitannya dengan dedikasi dan kinerja tenaga pendidikan dan kependidikan yang profesional serta keunggulan peserta didik dalam aktivitas belajar mengajar.

Dalam menyongsong era pasar bebas yang ketat dengan persaingan yang kompetetif sebagaimana dirilis oleh Bank Dunia bahwa kemungkinan akan berlaku di kawasan Asisa Pasifik pada tahun 2020. Untuk masuk ke dalam era persaingan tersebut dibutuhkan peserta didik yang tidak hanya cerdas, akan tetapi memiliki kompetensi yang baik dalam bidang keilmuan, khususnya keterampilan individu. Dengan adanya kompetensi dan skill individu diharapkan dapat menjadi motivasi dalam membentuk sumber daya manusia yang berkualitas dan profesional yang mampu menguasai IPTEK. Untuk tujuan tersebut, Sekolah Menengah Atas Nusantara kota Jambi menyediakan dua jurusan atau program keahlian yang

9 http://ypnnusantara.blogspot.com/2010/10/fasilitas-penunjang.html. Diakses tanggal 17 Februari 2013 
termasuk dalam program kejuruan Sekolah Menengah Kejuruan (SMK), yaitu program keahlian akuntansi dan program keahlian penjualan. ${ }^{10}$ Dan dalam rangka mengembangkan tugas penyiapan dan peningkatan SDM (Human Resources) Sekolah Menengah Atas Nusantara kota Jambi melaksanakan program akademik Kegiatan Belajar Mengajar di kelas, Praktik Laboratorium meliputi bidang ilmu Fiskia, Kimia, Biologi dan Komputer.

\section{Bentuk Manajerial Kepala SMA Nusantara dalam Kegiatan Baca Alquran}

\section{A. Pembinaan Materi Muatan Lokal Melalui Kegiatan Baca Alquran}

Bidang studi muatan lokal atau yang lebih akrab disebut dengan mulok di berbagai lembaga pendidikan di Indonesia pada prinsipnya merupakan pengembangan dari kurikulum nasional yang diramu sedemikian rupa dengan mengedepankan aspek budaya lokal dan mempertimbangkan kebutuhan dasar sosial masyarakat sekitar, khususnya stakeholder pendidikan yang ada di sekitarnya guna memenuhi kebutuhan peserta didik dalam memperkaya khazanah, budaya dan peradaban lokal di mana peserta didik hidup di dalamnya. Kurikulum muatan lokal dalam perspektif kurikulum nasional sebagaimana diatur dalam peraturan pemerintah sebagaimana SK Mendikbud No.0412/21/1987 tentang penerapan muatan lokal kurikulum sekolah (contoh dalam hal ini adalah sekolah dasar) muatan lokal diartikan sebagai program pendidikan yang isi dan media penyampaiannya dikaitkan dengan lingkungan alam, lingkungan sosial, dan lingkungan budaya serta kebutuhan pembangunan daerah yang perlu diajarkan kepada siswa. SK mendikbud tersebut di atas merupakan penjabaran dari Undang-Undang Republik Indonesia tahun 1989 Bab IX pasal 37 tentang sisdiknas menyatakan bahwa kurikulum disusun untuk mewujudkan tujuan pendidikan nasional denagn memperhatikan tahap perkembangan pesrta didik dan kesesuainnya dengan lingkungan kebutuhan pembangunan nasional, perkembangan IPTEK serta kesenian, sesuia dengan jenis dan jenjang masing-maing satuan pendidikan. Dan pada bab yang sama pasal 39 ayat (1), disebutkan bahwa pelaksanaan kegiatan pendidikan dalam satuan pendidikan didasarkan atas kurikulum yang berlaku secara nasional dan kurikulum yang disesuaikan dengan keadaan, serta kebutuhan lingkuingan dan ciri khas satuan pendidikan yang bersangkutan. ${ }^{11}$ Dan bila kita analisa secara serius keseluruhan UU RI No. 2 ternyata muatan lokal tidak tersurat tetapi tersirat dalam kedua pasal tersebut di atas. Dengan demikian, maka apabila dilihat dari aspek komponen kurikulum, muatan lokal merupakan isi kurikulum yang merupakan suatu bahan kajian dari mata pelajaran yng sesuai dengan keadaan dan kebutuhan lingkungan setempat. Atau dengan kata lain, bahwa kurikulum yang kemudian dipaparkan melalui sillabus di berbagai lembaga pendidikan di Indonesia diatur dan disusun berdasarkan kebutuhan pendidikan setempat dengan mengakomodir berbagai aspek, seperti budaya lokal, tradisi masyarakat setempat, paham keagamaan masyarakat setempat, dan berbagai aspek lainnya yang menjadi salah satu acuan pemikiran pendidikan.

\footnotetext{
${ }^{10}$ Dokumentasi Sekolah Menengah Atas Nusantara kota Jambi tahun 2013

${ }^{11} \mathrm{http}: / /$ www.latansaa.com/2013/03/makalah-prinsip-dasar-pengembangan.html. Diakses tanggal 11 Mei 2013 
Pembinaan baca Alquran dalam rangka pemberantasan buta aksara Alquran yang terintegrasi dalam materi pelajaran muatan lokal (mulok), tidak terlepas dari fungsi dan peran aktif penting pimpinan tertinggi dalam suatu lembaga pendidikan yang dalam hal ini adalah kepala sekolah. Peran kepala sekolah sebagai pimpinan tertinggi dalam konteks manajemen sekolah merupakan implementasi dari teori-teori manajemen yang telah dipaparkan oleh banyak pakar manajemen, sebut saja Storen yang menjelaskan bahwa bahwa manajemen merupakan proses perencanaan, pengorganisasian, pengarahan dan pengawasan usaha-usaha para anggota organisasi dan penggunaan sumber daya organisasi lainnya agar mencapai tujuan organisasi yang telah ditetapkan. ${ }^{12}$ Sehingga dalam menjalankan aktivitas organisasi selalu mengacu pada prinsip-prinsip organisasi yang mendudukkan pencapaian tujuan organisasi sebagai cita-cita bersama yang diimplementasikan dalam kegiatan belajar mengajar di sekolah. Kepala sekolah sebagai pemegang kendali organisasi bertanggung jawab atas kesuksesan seluruh program sekolah yang telah dicanangkan bersama.

Pengorganisasian seluruh elemen sekolah dalam kaitannya dengan pembinaan baca Alquran secara umum menjadi tanggung jawab kepala sekolah sebagai pimpinan tertinggi di sekolah tersebut, namun secara rinci dalam implementasi, maka guru PAI merupakan eksekutor terhadap berbagai kebijakan yang dikeluarkan kepala sekolah, terutama dalam kaitannya dengan pembinaan baca Alquran. Dengan demikian, maka relasi prosedural proses pembinaan baca Alquran di Sekolah Menengah Atas Nusantara kota Jambi menjadi tanggung jawab guru PAI sebagai pemangku amanah internalisasi nilai-nilai agama Islam terhadap peserta didik.

Pola manajemen yang diterapkan kepala sekolah dalam mengakomodir program utama pemerintah Provinsi Jambi dalam kaitannya dengan pemberantasan buta aksara Alquran pada prinsipnya tidak dilaksanakan secara spesifik atau mekanisme penerapannya dilakukan dalam pelajaran formal tertentu, tetapi aktivitas tersebut dilaksanakan dalam pembinaan materi keagamaan secara keseluruhan. Dan hal ini sesuai dengan Peraturan Pemerintah Republik Indonesia Nomor 55 tahun 2007 tentang Pendidikan Agama dan Pendidikan Keagamaan pada Bab II pasal 3 ayat 1 yang menyatakan bahwa setiap satuan pendidikan pada semua jalur, jenjang, dan jenis pendidikan wajib menyelenggarakan pendidikan agama. Dan kemudian dipertegas pada pasal 2 ayat 1 dan 2 yang menyatakan bahwa pendidikan agama berfungsi membentuk manusia Indonesia yang beriman dan bertakwa kepada Tuhan Yang Maha Esa serta berakhlakul mulia dan mampu menjaga kedamaian dan kerukunan hubungan inter dan antar umat beragama. Pendidikan agama bertujuan untuk berkembangnya kemampuan peserta didik dalam memahami, menghayati, dan mengamalkan nilai-nilai agama yang menyerasikan penguasaannya dalam ilmu pengetahuan, teknologi dan seni. ${ }^{13}$

Peraturan Pemerintah Republik Indonesia tersebut di atas kemudian diimplementasikan oleh seluruh kepala daerah di Indonesia, baik tingkat satu maupun tingkat kota dan kabupaten melalu berbagai prgoram-program

12 J.A.F. Stoneer, terj., Perencanaan dan Pengambilan Keputusan, (Jakarta: Erlangga, 1992), hlm. 9

${ }^{13}$ http://makalahmajannaii.blogspot.com/2012/12/pemberantasan-buta-aksara-wajibbelajar.html. Diakses 06 Mei 2013

Innovatio, Vol. XVII, No. 2, Juli-Desember 2017 
pendidikan di wilayah mereka masing-masing dalam rangka memberikan pendidikan yang mencerdaskan, khususnya pendidikan keagamaan. Dan secara spesifik pilot project pemerintah pusat tersebut diterapkan kepala-kepala sekolah di berbagai lembaga pendidikan sebagai praktisi pendidikan melalui pola-pola manajemen yang sesuai dengan wilayah dan lingkungan masing-masing.

Guna mengimplementasikan program Gubernur Jambi dalam rangka pemberantasan buta aksara Alquran, terutama kemampuan siswa-siswi dalam membaca Alquran di berbagai lembaga pendidikan, mulai dari Pendidikan Dasar hingga perguruan tinggi, kepala sekolah dan seluruh jajarannya melakukan berbagai terobosan dalam mewujudkan program tersebut, tanpa memandang status lembaga pendidikan yang bersangkutan, apakah itu negeri atau swasta. Optimalisasi yang dilakukan oleh kepala sekolah di masing-masing lembaga pendidikan tersebut beserta seluruh civitas akademik diarahkan pada bagaimana menciptakan lingkungan pendidikan yang akrab dengan kegiatan pemberantasan buta aksara Alquran.

Hal yang sama juga dilakukan di Sekolah Menengah Atas Nusantara kota Jambi, materi lokal sebagai bentuk dari pengembangan kurikulum telah mengakomodir pembinaan baca tulis Alquran, meskipun proses pembelajarannya terintegrasi dalam materi keagamaan. Ketika hal ini dikonfirmasikan kepada kepala sekolah dalam sebuah wawancara, penulis memperoleh informasi bahwa pembinaan baca tulis Alquran tidak diajarkan mutlak dalam satu jam pelajaran, akan tetapi inheren dalam kegiatan belajar mengajar agama Islam. Dan hal ini sesuai dengan pola manajemen rektrutmen peserta didik yang tidak mencantumkan syarat kemampuan baca tulis Alquran sebagai salah satu syarat diterimanya seorang siswa di sekolah tersebut. Adapun pembinaan baca Alquran semata-mata diberikan karena mayoritas siswa di Sekolah Menengah Atas Nusantara kota Jambi beragama Islam, dan masih ada beberapa siswa dalam jumlah tertentu yang belum bisa membaca Alquran, maka dari itu diberikan pengayaan baca Alquran yang terintegrasi dalam pelajaran agama. ${ }^{14}$

Dalam mengimplementasikan fungsi-fungsi manajemen yang di antaranya actuating atau aktualisasi program sekolah yang telah dicanangkan sebelumnya, kepala sekolah telah memberikan arahan kepada guru PAI dalam hal proses belajar mengajar bidang studi mulok untuk memberikan pengayaan membaca Alquran bagi siswa-siswi yang kurang bisa membaca Alquran. Dalam suatu wawancara penulis menyanyakan langsung kepada kepala sekolah perihal bimbingan baca Alquran dalam pelajaran mulok, dan secara langsung beliau menjelaskan bahwa dorongan untuk memberikan bimbingan baca Alquran bagi siswa-siswi yang kurang bisa membaca Alquran lebih disebabkan karena mayoritas peserta didik di sekolah ini adalah beragama Islam, sehingga dengan kecakapan membaca Alquran dapat mempermudah mereka dalam memahami pelajaran yang disampaikan oleh guru bidang studi. Adapun materi muatan lokal diberikan satu jam pelajaran (tatap muka) dalam satu minggu, sehingga masih ditemukan beberapa kendala dalam mengakomodir seluruh persoalan yang

${ }^{14}$ Kepala Sekolah SMA Nusantara Jaya Kasumantri, Wawancara, 02 Mei 2013, Jambi, Catatan Lapangan, Kegiatan pembinaan baca Alquran di Sekolah Menengah Atas Nusantara, Jambi. 
berkaitan dengan pembinaan baca Alquran. ${ }^{15}$ Informasi tersebut di atas menjelaskan bahwa alokasi waktu yang minim terhadap kegiatan pembinaan baca Alquran berimplikasi pada kesempatan yang diperoleh masing-masing siswa dalam melatih diri membaca Alquran, karena tidak dimungkinkan hanya dalam satu jam pelajaran (tatap muka) dapat mengakomodir problematika siswa dalam membaca Alquran. Hal yang sama juga disampaikan oleh guru bidang studi PAI yaitu M. Ridwan, S.Ag, beliau menjelaskan bahwa kepala sekolah mengarahkannya untuk memberikan materi mulok yang tidak hanya monoton pada materi tertentu, misalkan materi-materi fiqh sejarah dan sebagainya, tetapi juga diperkaya dengan pemberian bimbingan baca Alquran bagi peserta didik yang tidak bisa baca Alquran. Dan kondisi ini memang dirasakan oleh guru bidang studi bahwa peserta didik yang tidak mempunyai kemampuan baca Alquran mengalami kesulitan dalam menerima pelajaran yang memuat bacaan Alquran dan hadits Nabi Muhammad Saw. ${ }^{16}$

Untuk memberikan dukungan validasi data yang akurat terhadap datadata informasi yang penulis terima dari beberapa hasil wawancara tersebut di atas, maka dilakukan observasi di lapangan penelitian, di mana observasi ini dilakukan untuk melakukan cross check terhadap data verbal yang diperoleh melalui wawancara. Dalam penelusuran dan pengamatan ini, penulis melakukan pengamatan terhadap aktivitas belajar mengajar bidang studi mulok yang disampaikan langsung oleh Bapak M. Ridwan, S.Ag, guru PAI Sekolah Menengah Atas Nusantara kota Jambi. Dalam kegiatan tersebut, penulis memperoleh informasi bahwa guru PAI dalam memberikan materi pelajaran, tidak semata-mata menyampaikan materi sebagaimana tertuang dalam sillabus pelajaran mulok, tetapi disela-sela pembelajaran yang sedang berlangsung, guru PAI memberikan bimbingan belajar baca Alquran yang baik terhadap beberapa siswa-siswi yang belum bisa membaca Alquran dengan cara meminta siswa yang bersangkutan untuk membuka Alquran yang berkaitan dengan materi ajar yang disampaikan kemudian diminta untuk membaca ayat-ayat yang berkaitan tersebut dan apabila ditemukan kendala dalam proses tersebut, maka guru langsung memberikan bimbingan dan arahan tentang cara membaca Alquran yang baik dan benar. ${ }^{17}$

Berdasarkan hasil dari wawancara dan pengamatan lapangan tentang pembinaan muatan lokal dengan kegiatan baca Alquran tersebut di atas, penulis menyimpulkan bahwa kegiatan pembinaan baca Alquran dalam rangka pemberantasan buta aksara Alquran sebagaimana telah dikemukakan sebelumnya pada prinsipnya tidaklah semata-mata diperuntukkan atau dialokasikan waktu khusus untuk kegiatan pembinaan bacaan Alquran, tetapi pembinaan tersebut secara inheren terintegrasi dalam proses belajar mengajar bidang studi muatan lokal. Menindaklanjuti pengamatan penulis dalam hal proses bimbingan baca Alquran yang dilakukan oleh guru PAI di Sekolah Menengah Atas Nusantara kota

\footnotetext{
15 Kepala Sekolah SMA Nusantara Jaya Kasumantri, Wawancara, 04 Mei 2013, Jambi, Catatan Lapangan, Bimbingan baca Alquran di Sekolah Menengah Atas Nusantara, Jambi.

16 Guru PAI SMA Nusantara M. Ridwan, Wawancara, 06 Mei 2013, Jambi, Catatan Lapangan, Integrasi bidang studi muatan lokal dengan bimbingan baca Alquran di Sekolah Menengah Atas Nusantara, Jambi.

17 Observasi, 13 Mei 2013 tentang bentuk bimbingan guru PAI Sekolah Menengah Atas Nusantara terhadap siswa-siswi yang belum mampu membaca Alquran dengan baik. 
Jambi, penulis kemudian menguji kembali validalitas informasi tersebut di atas dengan mengamati aktivitas guru PAI dalam menyampaikan materi muatan lokal di lain kesempatan. Pengamatan penulis di lapangan penelitian kali ini menunjukkan bahwa tidak seluruh kelas mendapatkan perlakuan yang sama dalam hal pembinaan baca Alquran. Misalnya di kelas XI IPS, guru PAI tidak memberikan materi pengayaan baca Alquran sebagaimana yang dilakukannya di kelas lain, hal ini ternyata dilakukan guru PAI karena rata-rata siswa-siswi di kelas yang bersangkutan memiliki kemampuan baca Alquran yang cukup memadai untuk mempelajari bidang studi muatan lokal, sehingga guru yang bersangkutan tidak merasa kesulitan dalam menyampaikan materi pelajaran di depan kelas. ${ }^{18}$

Berdasarkan hasil analisa dari beberapa informasi tersebut di atas, penulis berkesimpulan bahwa pelaksanaan pembinaan bacaan Alquran di Sekolah Menengah Atas Nusantara kota Jambi tidak berdiri sendiri atau dialokasikan waktu khusus sebagaimana pelajaran lain. Pembinaan baca Alquran yang dilakukan guru PAI terintegrasi dalam bidang studi muatan lokal, dengan memperhatikan kemampuan baca Alquran siswa-siswi pada masing-masing kelas. Adapun pola pembinaan baca Alquran dilakukan dengan model face to face dimana siswa yang membaca Alquran diberikan arahan langsung oleh guru apabila siswa yang bersangkutan melakukan kesalahan dalam bacaannya.

Setelah menganalisa data-data yang diperoleh dari informasi wawancara dan beberapa pengamatan di lapangan penelitian, maka penulis menemukan titik poin dari pola manajemen kepala Sekolah Menengah Atas Nusantara kota Jambi dalam kaitannya dengan pembinaan materi muatan lokal melalui kegiatan baca Alquran, bahwa fungsi actuating sebagai salah satu fungsi dari beberapa fungsi manajemen yang diterapkan kepala sekolah lebih dominan diterapkan kepala sekolah dibandingkan fungsi manajemen yang lainnya, hal ini dapat penulis kemukakan dari salah indikator yang dapat dijadikan acuan dalam merumuskan kesimpulan tersebut bahwa setelah kegiatan belajar mengajar berlangsung di Sekolah Menengah Atas Nusantara kota Jambi, kepala sekolah menyampaikan langsung arahannya kepada guru PAI untuk memberikan pembinaan bacaan Alquran terhadap siswa yang kurang mampu membaca Alquran dalam proses belajar mengajar bidang studi muatan lokal tanpa pengalokasian waktu khusus terhadap kegiatan tersebut.

\section{B. Pengelolaan Bidang Studi Keagamaan dalam Meningkatkan Kemampuan Baca Alquran}

Dalam menanamkan nilai-nilai keislaman pada diri peserta didik, seluruh elemen sekolah memiliki peran yang sama dalam memberikan dukungan dan dorongan terhadap pembentukan akhlakul karimah yang dimulai dari penanaman nilai-nilai tersebut dalam aktivitas belajar mengajar. Sebagai follow up dari internalisasi nilai-nilai Islam tersebut, dibutuhkan pengelolaan kegiatan keagamaan yang baik dalam pembentukan karakter peserta didik, khususnya dalam mewujudkan kemampuan peserta didik dalam membaca Alquran. Untuk mewujudkan tujuan tersebut di atas, dibutuhkan peran kepala sekolah dalam menata dan mengelola seluruh komponen sekolah dengan memanfaatkan sumber daya manusia dan

18 Observasi, 18 Mei 2013 tentang pembinaan baca Alquran melalui mata pelajaran muatan lokal di Sekolah Menengat Atas Nusantara Kota Jambi. 
sumber belajar yang ada dalam menciptkan lingkungan belajar yang kondusif, terutama dalam pengembangan dan peningkatan kemampuan baca Alquran.

Bidang studi keagamaan merupakan salah satu materi pelajaran yang terjadwal secara resmi dalam roster belajar, model pembelajaran yang digunakan adalah all one system atau dalam istilah Arab dikenal نظرية الوحدة yang maksudnya bahwa materi pelajaran agama diberikan dalam satu jam pelajaran yang terdiri dari beberapa disiplin ilmu keislaman, seperti fiqh, sejarah kebudayaan Islam, bahasa Arab, hadits dan beberapa disiplin ilmu keislaman lainnya. Dalam melakukan pemetaan terhadap kegiatan belajar mengajar tersebut di atas, guru PAI harus memiliki wawasan yang luas tentang keislaman. Dan kondisi tersebut jauh berbeda apabila dibandingkan kurikulum terapan Kementerian Agama yang diimplementasikan dalam kurikulum berbagai pendidikan yang berciri khas Islam, khususnya madrasah. Di mana materi keagamaan dalam institusi madrasah menggunakan model نظرية الفروع yang maksudnya bahwa materi keagamaan berdiri sendiri dalam proses belajar mengajar, misalnya pelajaran Alquran Hadits, Akidah Akhlak, Sejarah dan Kebudayaan Islam, Bahasa Arab, dan Fiqh.

Ketika persoalan tersebut di atas ditanyakan kepada kepala sekolah melalui wawancara, kepala sekolah menyampaikan kepada penulis bahwa Sekolah Menengah Atas Nusantara kota Jambi menerapakn model pembelajaran materi keagamaan dengan model all in one system, dalam arti kata bahwa seluruh materi keagamaan yang terangkum dalam kurikulum sekolah diberikan dalam satu bidang studi. Untuk bidang studi keagamaan dialokasikan 2 jam pelajaran dalam satu minggu, dan oleh karena itu guru PAI di sekolah ini diarahkan untuk memberikan materi keagamaan sesuai dengan porsi waktu yang tersedia, termasuk kegiatan pembinaan baca Alquran. ${ }^{19}$ Hal yang senada juga disampaikan oleh guru PAI Sekolah Menengah Atas Nusantara kota Jambi yang dalam hal ini adalah Bapak M. Ridwan, S.Ag dalam sebuah kesempatan wawancara dengan penulis mengatakan bahwa materi keagamaan diberikan 2 jam dalam satu minggu, di mana seluruh materi keagamaan yang ada dalam sillabus dielaborasi secara keseluruhan dengan melakukan pemilahan materi mana yang diberikan terlebih dahulu sesuai dengan prosedur pembelajaran yang telah disusun. Maka ketika materi yang disampaikan memuat ayat-ayat Alquran, disediakan beberapa Alquran sebagai pegangan peserta didik yang kurang mampu membaca Alquran. Kemudian masing-masing siswa yang kurang baik bacaannya, diberikan bimbingan secara langsung tentang cara membaca Alquran yang baik dan benar. ${ }^{20}$

Pengelolaan bidang studi keagamaan dalam kaitannya dengan implementasi fungsi-fungsi manajemen, pada prinsipnya mengacu pada konsep teoritis dan praktis, di mana fungsi manajemen sebagai acuan dasar dalam penataan dan pengelolaan berbagai aktivitas organisasi, sementara pelaksanaan bimbingan keagamaan adalah wujud nyata dari penerapan fungsi-fungsi tersebut. Oleh sebab itu, pencapaian tujuan organisasi harus sejalan antara dejure dan

\footnotetext{
${ }^{19}$ Kepala Sekolah SMA Nusantara Jaya Kasumantri, Wawancara, 13 Mei 2013, Jambi, Catatan Lapangan, Pengelolaan materi keagamaan dalam meningkatkan baca Alquran di Sekolah Menengah Atas Nusantara, Jambi.

${ }^{20}$ Guru PAI SMA Nusantara M. Ridwan, Wawancara, 14 Mei 2013, Jambi, Catatan Lapangan, Kegiatan pembinaan baca Alquran bagi siswa yang kurang mampu membaca Alquran yang teintegrasi dalam materi pelajaran keagamaan di Sekolah Menengah Atas Nusantara, Jambi. 
defacto. Kepala sekolah dalam perannya sebagai pimpinan tertinggi dalam sebuah lembaga pendidikan harus menjadikan fungsi-fungsi manajemen sebagai landasan dalam mengambil kebijakan dan keputusan. Bentuk manajerial yang diterapkan kepala sekolah dalam pengembangan materi keagamaan melalui pembinaan bacaan Alquran di Sekolah Menengah Atas Nusantara kota Jambi lebih mengarah pada manajemen sumber daya manusia. Hal ini dapat dilihat dari bagaimana sikap kepala sekolah memainkan perannya dengan mengarahkan, memberikan saran dan menugaskan guru PAI dalam pemberantasan buta aksara di sekolah yang dipimpinnya. Dan ketika dikonfirmasikan perihal tersebut di atas melalui wawancara, beliau menyatakan bahwa satu hal yang sulit dalam pengembangan sebuah lembaga pendidikan, yakni bagaimana mensinergikan seluruh elemen sekolah dalam menjalankan seluruh program sekolah. Pola pendekatan yang dilakukan kepala sekolah dalam mengarahkan guru PAI adalah individual approach atau pendekatan individu. Model pendekatan ini dilakukannya dengan cara mendudukkan masing-masing individu pada posisi masing-masing dengan mengesampingkan prinsip atasan dan bawahan. Sehingga dengan demikian menurutnya akan terbangun konsep kebersamaan dalam menjalankan tugas dan tanggung jawab. ${ }^{21}$

Statemen tersebut di atas dibenarkan guru bidang studi PAI, yaitu Bapak M. Ridwan, S.Ag sebagaimana disampaikannya dalam sebuah wawancara dengan penulis. Menurutnya, dalam mewujudkan program pemberantasan buta aksara Alquran, kepala sekolah sering berkomunikasi dengannya melalui diskusi singkat tentang bagaimana membimbing siswa-siswi yang kurang mampu membaca Alquran, sehingga mereka dapat memiliki kemampuan baca Alquran dengan baik. Lebih lanjut menurutnya, program pemberantasan buta aksara Alquran tesebut kadang-kadang disampaikan kepala sekolah dalam berbagai kesempatan rapat umum dewan guru. Dengan demikian, maka sesungguhnya persoalan pemberantasan buta aksara Alquran bukanlah semata-mata menjadi tanggung jawab guru PAI sebagai penanggung jawab materi-materi keagamaan, tetapi secara eksplisit menjadi tanggung jawab seluruh elemen sekolah dalam mengembangkan kemampuan baca Alquran di Sekolah Menengah Atas Nusantara kota Jambi. ${ }^{22}$

Langkah-langkah manajerial yang dilakukan kepala sekolah dalam pemberantasan buta aksara Alquran melalui kegiatan belajar mengajar materi keagamaan secara teoritis dan praktis sesuai dengan konsep manajemen sumber daya manusia yang dikembangkan Simamora sebagaimana dikutip Edi Sutrisno bahwa manajemen sumber daya manusia merupakan suatu upaya pendayagunaan, pengembangan, penilaian, pemberian balas jasa, dan pengelolaan individu anggota organisasi atau kelompok pekerja. ${ }^{23}$

Pembinaan baca Alquran melalui kegiatan belajar mengajar bidang studi keagamaan di Sekolah Menengah Atas Nusantara kota Jambi dilaksanakan dalam bentuk klasikal dengan menerapkan dua model pembelajaran, yaitu:

${ }^{21}$ Kepala Sekolah SMA Nusantara Jaya Kasumantri, Wawancara, 18 Mei 2013, Jambi, Catatan Lapangan, Penerapan manajemen sumber daya manusia dalam pembinaan bidang studi keagamaan di Sekolah Menengah Atas Nusantara, Jambi.

22 Guru PAI SMA Nusantara M. Ridwan, Wawancara, 18 Mei 2013, Jambi, Catatan Lapangan, Program pemberantasan buta aksara Alquran di Sekolah Menengah Atas Nusantara, Jambi.

23 Edy Sutrisno, Manajemen Sumber Daya Manusia, (Jakarta: Kencana, 2011), cet. ke- 3, hlm. 5 


\section{Talfidz}

Talfidz merupakan salah satu pola belajar mengajar tradisional yang masih digunakan dalam pembelajaran baca Alquran dewasa ini, meskipun tidak sepopuler dengan metode belajar Alquran lainnya yang didukung dengan media audio visual modern. Model belajar mengajar talfidz tergolong metode mengajar yang cukup sederhana, karena dapat dilakukan secara langsung tanpa menggunakan media belajar pendukung lainnya. Metode tersebut dapat digunakan dalam suasana belajar, baik yang bersifat klasikal maupun non klasikal, individual maupun kelompok. Model belajar mengajar talfidz dapat dilakukan dengan membacakan satu naskah berbahasa Arab atau potongan-potongan ayat Alquran atau hadits Nabi, kemudian diulangi kembali pengucapannya oleh peserta didik setelah mendapatkan perintah dari guru pengasuh.

Dalam suatu wawancara dengan guru bidang studi PAI Sekolah Menengah Atas Nusantara kota Jambi, penulis meminta tanggapannya tentang pembinaan baca Alquran dengan cara talfidz. Beliau menyampaikan bahwa dalam proses belajar mengajar materi keagamaan, khususnya mengajarkan baca Alquran, cara talfdiz pada dasarnya diperuntukkan bagi siswa-siswi yang belum mengenal seutuhnya huruf hijaiyyah, sehingga mereka harus diajarkan cara mengucapkan huruf hijaiyyah atau kalimat bahasa Arab. Hal ini dilakukan untuk melatih dan membiasakan lidah dalam mengucapkan huruf hijaiyyah atau kata-kata dalam bahasa Arab, termasuk ayat-ayat Alquran dan hadits Nabi. Dalam kegiatan talfidz ini, guru mengucapkan huruf hijaiyyah tertentu atau potongan ayat Alquran tertentu, kemudian diikuti oleh seluruh siswa dalam kelas. Setelah dianggap cukup terampil, guru kemudian meminta siswa yang tidak bisa membaca Alquran untuk mengulangi beberapa kali hingga ucapannya fasih dan benar sesuai dengan bunyi makharijul huruf..$^{24}$

Pendapat tersebut di atas diperkuat dengan ungkapan Bapak Adrianus, S. Pd selaku wakil kepala sekolah bidang kurikulum dalam sebuah wawancara dengan penulis. Beliau menyatakan bahwa dalam proses belajar mengajar bidang studi keagamaan, kegiatan pengucapan huruf-huruf hijaiyyah atau potongan ayat Alquran tertentu dapat didengarkan dengan jelas dari luar ruang belajar. Dan model belajar dengan cara talfidz tersebut dilaksanakan di setiap pelajaran materi keagamaan, dan peserta didik yang mengikuti kegiatan belajar mengajar tersebut terlihat antusias dalam mengikuti proses belajar mengajar. ${ }^{25}$

Dari hasil wawancara tersebut di atas yang kemudian didukung oleh datadata lapangan yang dilakukan melalui observasi, penulis menyimpulkan bahwa dalam kegiatan belajar mengajar bidang studi keagamaan, khususnya pembinaan baca Alquran siswa-siswi di Sekolah Menengah Atas Nusantara kota Jambi, guru PAI menggunakan metode talfidz dalam mengucapkan huruf-huruf hijaiyyah dan beberapa potongan ayat Alquran dan hadits Nabi. Dan secara spesifik fokus pembinaannya ditujukan kepada siswa-siswi yang belum bisa membaca Alquran

${ }^{24}$ Guru PAI SMA Nusantara M. Ridwan, Wawancara, 20 Mei 2013, Jambi, Catatan Lapangan, Penggunaan metode talfidz dalam bimbingan baca Alquran di Sekolah Menengah Atas Nusantara, Jambi.

25 Wakabid Kurikulum SMA Nusantara Adrianus, Wawancara, 20 Mei 2013, Jambi, Catatan Lapanga, Penggunaan metode talfidz dalam mengajar baca Alquran di Sekolah Menengah Atas Nusantara, Jambi. 
dengan fasih sesuai tata baca Alquran yang benar. Data-data tersebut di atas juga mengindikasikan bahwa metode talfidz digunakan dalam pembinaan baca Alquran peserta didik pemula atau belum sepenuhnya menguasai tata baca Alquran dengan benar dan fasih.

Dalam teori baca Alquran sebagaimana diungkapkan Sa'dulloh bahwa talfidz merupakan salah satu strategi cara belajar Alquran dengan pengenalan dan pengucapan bunyi huruf-huruf hijaiyyah sebagai huruf dasar dalam penerapan bacaan yang berkelanjutan. Strategi tersebut dimulai dengan memahami dan mengucapkan tiap huruf dan perubahannya, baik dalam bentuk huruf dasar, awal, tengah, maupun bentuk akhir. Dan sebagai tindak lanjut dari pemahaman tersebut di atas, diteruskan dengan membaca dan melafalkan kata demi kata baik yang berdiri sendiri maupun bersambung yang telah tersusun secara bertahap dan berurutan. ${ }^{26}$

Kegiatan yang telah dilakukan guru PAI Sekolah Menengah Atas Nusantara kota Jambi dalam pembinaan baca Alquran pada prinsipnya sejalan dengan teori belajar baca Alquran yang dikembangkan oleh pakarnya, hanya saja dominasi peruntukannya lebih difokuskan pada peserta didik pemula yang belum menguasai secara baik dan benar terhadap tata cara membaca Alquran. Dan hal ini dapat dipahami bahwa alokasi waktu dan kesempatan dalam kaitannya dengan pembinaan baca Alquran masih terintegrasi dalam bidang studi keagamaan yang cakupan materinya cukup luas dan tidak hanya diperuntukkan pada kegiatan pengembangan dan peningkatan bacaan Alquran.

2. Demonstrasi

Metode demonstrasi dalam kaitannya dengan pembinaan baca Alquran sesungguhnya memiliki persamaan dalam proses belajar mengajar materi pelajaran lainnya seperti bahasa Indonesia, bahasa Inggris, bahasa Arab dan pelajaran lainnya. Dalam proese belajar baca Alquran, guru bidang studi memberikan contoh-contoh bacaan Alquran dan hadits, baik yang pendek, sedang dan panjang yang kemudian diperdengarkan dan dipraktekkan secara langsung di depan peserta didik. Dalam beberapa kesempatan, guru bidang studi membacakan beberapa potongan ayat dengan menggunakan lagu selayaknya bacaan qori', meskipun sifatnya sangat sederhana sekali. Bacaan tersebut didemonstrasikan di depan kelas dengan menerapkan hukum bacaan tajwid yang benar dan fasih, sehingga peserta didik dapat memahami dengan baik tentang bacaan yang pendek atau panjang.

Menampilkan bacaan Alquran yang fasih di depan kelas meruapakan perkaran yang tidak mudah, karena tidak memungkingkan seluruh peserta didik dapat menerima dan memahami pelajaran yang disampaikan dengan baik dan sempurna, hal ini mengangat bahwa jumlah peserta didik dalam satu ruang belajar cukup banyak sehingga menyulitkan guru PAI memahami karakter daya tangkap masing-masing peserta didik. Namun demikian, dengan menampilkan contohcontoh bacaan Alquran yang fasih di hadapan kelas telah memberikan nuansa karakteristik bacaan Alquran yang baik, meskipun membutuhkan proses dan waktu yang cukup panjang.

${ }^{26}$ Sa'dulloh, Metode Qur'any: Belajar Baca Alquran Untuk Semua Umur, (Yogyakarta: Mutiara Media, 2010), hlm. 3 
Untuk mendapatkan informasi langsung mengenai bimbingan bacaan Alquran melalui demonstrasi ini, penulis mewawancarai langsung guru PAI dan meminta klarifikasinya tentang bagaimana mengajarkan bacaan Alquran dengan metode demonstrasi tersebut. Dalam kesempatan wawancara tersebut, guru PAI menjelaskan bahwa mendemonstrasikan bacaan Alquran dengan fasih yang berkaitan dengan materi keagamaan dilakukan dengan menampilkan bacaan beberapa potongan ayat Alquran yang cukup populer di telingan peserta didik seperti pembacaan surat-surat pendek. Lebih lanjut menurutnya, bahwa pembelajaran Alquran melalui demonstrasi ini pada prinsipnya diberikan bagi peserta didik yang telah memiliki kemampuan dasar baca Alquran, sehingga fokus pembelajaran lebih diarahkan pada pembentukan karakter bacaan yang benar dan fasih. ${ }^{27}$

Adapun metode demonstrasi yang digunakan guru PAI dalam proses belajar mengajar Alquran merupakan sebagai upaya yang dilakukan guru PAI sebagai penanggung jawab materi keagamaan dalam pembinaan baca Alquran khususnya, dan pembinaan materi keagamaan pada umumnya. Pemberian contoh bacaan Alquran yang fasih dalam bentuk kelompok dengan pola menirukan bacaan guru, dianggap satu pola pembelajaran yang dapat mengakomodir keterbatasan peserta didik dalam mempelajari tata cara membaca Alquran. Ketika hal ini dikonfirmasikan kepada guru PAI dalam sebuah wawancara, beliau kemudian menjelaskan bahwa perbedaan kemampuan baca Alquran peserta didik, mulai dari mampua membaca Alquran dengan fasih sesuai hukum tajwid, mampu membaca tetapi belum sepenuhnya sesuai hukum tajwid, mampu membaca tetapi melalui ejaan, dan mereka yang tidak bisa sama sekali membaca Alquran membutuhkan cara belajar tersendiri yang dapat mengakomodir perbedaan kemampuan tersebut. Lebih lanjut ia mengemukakan bahwa metode demonstrasi dengan cara guru membaca Alquran dan kemudian diikuti seluruh peserta didik menjadi salah satu alternatif dalam proses belajar mengajar, di mana metode ini dapat membiasakan lidah mereka melafalkan bacaan-bacaan yang fasih sesuai dengan hukum tajwid yang berlaku. ${ }^{28}$

Hal yang sama disampaikan kepala sekolah dalam sebuah wawancara dengan penulis. Menurut beliau, dalam melakukan penataan personalia guru dalam kaitannya dengan aktivitas belajar mengajar biasanya disampaikan dalam bentuk musyawarah guru mata pelajaran di lingkungan Sekolah Menengah Atas Nusantara kota Jambi dengan menghadirkan beberapa pemateri yang dianggap mahir dalam bidang tersebut. Dalam kegiatan tersebut, guru-guru diberikan kesempatan yang seluas-luasnya untuk menyampaikan persoalan-persoalan yang dihadapi dalam proses belajar mengajar. Kegiatan MGMP semakin menarik tatkala beberapa guru menjelaskan problematika yang dihadapi dalam proses belajar, tak terkecuali guru PAI. Dengan tegas guru PAI menjelaskan bahwa adanya perbedaan kemampuan baca Alquran siswa-siswi Sekolah Menengah Atas Nusantara kota

27 Guru PAI SMA Nusantara M. Ridwan, Wawancara, 9 April 2013, Jambi, Catatan Lapangan, Pembelajaran bacaan Alquran dengan menggunakan metode demonstrasi di Sekolah Menengah Atas Nusantara, Jambi

${ }^{28}$ Guru PAI SMA Nusantara M. Ridwan, Wawancara, 18 April 2013, Jambi, Catatan Lapangan, Penggunaan metode demonstrasi dalam kegiatan belajar mengajar Alquran di Sekolah Menengah Atas Nusantara kota Jambi 
Jambi membutuhkan penanganan khsusus, dalam arti kata bahwa alokasi waktu untuk pembinaan baca Alquran bagai peserta didik yang tidak memiliki kemampuan baca Alquran perlu didukung alokasi waktu di luar jam pelajaran resmi yang secara administrasi kurikulum terintegrasi dalam bidang studi agama. $^{29}$

Untuk menguji validitas data, penulis melakukan pengamatan langsung di lapangan penelitian dengan mengamati proses belajar mengajar baca Alquran dalam mata pelajaran agama yang diasuh langsung oleh guru PAI Sekolah Menengah Atas Nusantara kota Jambi. Dalam pengamatan tersebut, penulis memperoleh data lapangan bahwa salah satu metode yang digunakan guru PAI dalam proses belajar mengajar baca Alquran adalah metode demonstrasi. Dengan metode ini, guru dapat memberikan pembiasaan peserta didik dalam membaca ayat-ayat Alquran dengan menggunakan lafal yang benar sesuai hukum tajwid, meskipun sulit membuktikan kebenaran bacaan peserta didik pada saat mereka membaca sendiri ayat-ayat Alquran lainnya di luar bimbingan guru. Hal ini tampak pada saat mana guru meminta peserta didik untuk membaca ayat yang lain di luar ayat yang telah mereka pelajari sebelumnya, mereka tampak kaku dalam bacaan dan sulit membedakan antara bacaan yang panjang dan pendek atau yang disebut dalam ilmu tajwid sebagai hukum bacaan mad. Sehingga guru membetulkan bacaan tersebut dan kemudian diikuti oleh seluruh siswa-siswa. ${ }^{30}$

Dalam kerangka analisa data-data yang bersumber dari informan dan kemudian dipadukan dengan data-data lapangan yang diperoleh melalui pengamatan lapangan, penulis kemudian menyimpulkan bahwa metode demonstrasi yang digunakan guru PAI dalam proses belajar mengajar Alquran lebih disebabkan karena minimnya alokasi waktu belajar mengajar Alquran, sementara perbedaan kemampuan baca Alquran peserta didik di Sekolah Menengah Atas Nusantara kota Jambi yang cukup signifikan harus mendapatkan solusi dalam rangka pengentasan buta aksara Alquran di lembaga pendidikan tersebut. Dengan demikian, maka dalam rangka pencapaian program pemerintah yang berkaitan dengan pemberantasan buta aksara Alquran dibutuhkan tambahan alokasi waktu di luar jam pelajaran resmi. Namun demikian, penambahan alokasi waktu yang dikhususkan pembinaan bacaan Alquran tergantung dari bagaimana peran kepala sekolah dalam melakukan penataan dan pengelolaan administrasi sekolah, sehingga porsi waktu pembinaan bacaan Alquran dapat bertambah sesuai kebutuhan.

\section{Pemanfaatan Kegiatan Intrakurikuler dan Ekstrakurikuler dalam Peningkatan Kualitas Baca Alquran}

Kegiatan intrakurikuler dan ekstrakurikuler dalam suatu lembaga pendidikan tidak dapat dipisahkan, kedua aspek tersebut merupakan modal utama dalam mengembangkan program pendidikan sebagai sebuah proses dalam mencapai

29 Kepala Sekolah SMA Nusantara Jaya Kasumantri, Wawancara, 18 April 2013, Jambi, Catatan Lapangan, Perlunya penambahan waktu belajar baca Alquran di luar jam pelajaran resmi di Sekolah Menengah Atas Nusantara, Jambi.

30 Observasi, 18 April 2013 tentang kegiatan belajar Alquran di Sekolah Menengah Atas Nusantara kota Jambi. 
tujuan yang telah ditetapkan. Dan kedua kegiatan tersebut secara implisit berimplikasi langsung pada out put pendidikan di samping komponen pendidikan lainnya. Dalam logika sederhana dapat dikatakan bahwa pengelolaan kegiatan intrakurikuler dan ekstrakurikuler yang baik dalam kaitannya dengan proses pendidikan berdampak pada produk pendidikan yang dihasilkan. Dengan demikian, maka dibutuhkan pola manajemen yang baik dan sesuai dengan kondisi sekolah dan stakeholder yang mengitarinya. Sekolah sebagai organisasi membutuhkan tenaga-tenaga profesional yang dapat menata dan mengelola seluruh elemen sekolah dalam rangka menjalankan aktivitas organisasi dalam rangka mewujudkan cita-cita dan tujuan organisasi. Kepala sekolah sebagai top leader sangat berperan dalam menentukan kebijakan dan langkah-langkah progress untuk memenuhi kebutuhan peserta didik khususnya dan sekolah sebagai lembaga pendidikan merupakan wadah aktivitas manusia pada umumnya. Sebagaimana telah dikemukakan pada pembahasan sebelumnya bahwa dalam pengelolaan dan penataan aktivitas manusia dibutuhkan manajemen kinerja sumber daya manusia yang dalam pandangan S. Ruky sebagaimana dikutip A.A. Anwar Prabu Mangkunegara merupakan bentuk usaha kegiatan atau program yang diprakarsai dan dilaksanakan oleh pimpinan organisasi atau perusahaan untuk mengarahkan dan mengendalikan prestasi karyawan. ${ }^{31}$ Demikian halnya dalam pandangan Robert Bacal sebagaimana dikutp A.A. Anwar Prabu Mangkunegara bahwa manajemen kinerja sumber daya manusia merupakan suatu proses komunikasi yang terus menerus, dilakukan dalam kerangka kerjasama antara seorang karyawan dan atasannya langsung, yang melibatkan penetapan pengharapan dan pengertian tentang fungsi kerja karyawan yang paling dasar, bagaimana pekerjaan karyawan memberikan kontribusi pada sasaran organisasi, makna dalam arti konkrit untuk melakukan pekerjaan dengan baik, bagaimana prestasi kerja akan diukur, rintangan yang mengganggu kinerja dan cara untuk meminimalkan atau melenyapkan. ${ }^{32}$

Berdasarkan beberapa pandangan dari teori tersebut di atas, maka dalam pengelolaan seluruh komponen sekolah, kepala sekolah sebaiknya menguasai betul bagaimana menerapkan manajemen sumber daya manusia dalam kaitannya dengan pendidikan yang mencerdaskan. Satu hal yang harus diperhatikan dalam pengelolaan pendidikan sekolah adalah bagaimana membentuk komunikasi yang baik antara seluruh elemen sekolah, terutama dalam mengkomunikasi programprogram pendidikan guna mewujudkan visi dan misi sekolah. Pada pembahasan ini akan dikemukakan upaya-upaya yang dilakukan kepala sekolah dan guru PAI sebagai penanggung jawab langsung program pemberantasan buta aksara Alquran di Sekolah Menengah Atas Nusantara kota Jambi. Upaya-upaya tersebut secara terperinci dalam dua kegiatan penting sekolah, yaitu kegiatan intrakurikuler dan kegiatan ekstrakurikuler.

1. Kegiatan Intrakurikuler

Intrakurikuler merupakan kegiatan pokok dalam pengelolaan sekolah secara keseluruhan, di mana kegiatan ini dimaksudkan bagaimana kegiatan belajar mengajar dapat dilaksanakan sesuai dengan fungsi-fungsi manajemen dalam

31 A.A. Anwar Prabu Mangkunegara, Evaluasi Kinerja SDM, (Bandung: PT. Refika Aditama, 2010), cet. ke- 5, hlm. 19

32 A.A. Anwar Prabu Mangkunegara, Ibid., 
rangka mewujudkan cita-cita dan tujuan organisasi. Setiap institusi pendidikan memiliki kegiatan intrakurikuler yang diharapkan dapat memberikan kontribusi positif dalam menghasilkan out put pendidikan yang cerdas dan terampil sesuai dengan kebutuhan masyarakat sebagai pengguna jasa lulusan dari institusi pendidikan yang dimaksud, baik dalam aspek ekonomi, sosial, pemerintahan dan masyarakat itu sendiri.

Pada umumnya, kegiatan intrakurikuler lebih dikenal dengan kegiatan belajar mengajar formal di kelas berbasis kurikulum pendidikan pada masingmasing lembaga pendidikan. Sekolah Menengah Atas Nusantara kota Jambi sebagaimana sekolah-sekolah lain telah menjalankan perannya sebagai wadah pendidikan melalui aktivitas belajar mengajar berbagai disiplin ilmu sebagaimana dituangkan dalam jadwal pelajaran. Kegiatan ini sudah berjalan sejak awal berdirinya hingga saat ini dengan selalu mengikuti perkembangan pendidikan guna melakukan penyesuaian-penyesuaian terhadap berbagai kebutuhan pendidikan persekolah.

Berbicara tentang kegiatan intrakurikuler pada dasarnya membicarakan kurikulum sekolah sebagai pedoman utama proses belajar mengajar. Sekolah Menengah Atas Nusantara kota Jambi sebagai salah satu lembaga pendidikan yang berafiliasi pada pendidikan umum, dalam penerapan kurikulum sekolah mengacu pada kurikulum terapan Kementerian Pendidikan Nasional yang dalam hal ini Dinas Pendidikan dan Kebudayaan kota Jambi. Dalam kurikulum terapan tersebut, bidang studi agama dialokasikan satu pertemuan dalam satu minggu. Dan berbeda misalnya, ketika bidang studi diajukan adalah bidang studi eksakta, seperti matematika, kimia, fisika dan materi-materi eksakta lainnya yang mendapat alokasi waktu dua hingga empat pertemuan dalam satu minggu. Adanya perbedaan ini mengindikasikan bahwa ternyata materi keagamaan mendapat porsi sedikit dibandingkan materi-materi lainnya. Sehingga dengan demikian, maka dalam proses belajar mengajar bidang studi keagamaan, termasuk di dalamnya pembinaan baca Alquran materi ajar harus dipadatkan agar sillabus yang telah disusun dapat dilaksanakan sebagaimana pembagian alokasi waktu. Dalam kaitannya dengan kurikukum sekolah ketika dikonfirmasikan dengan kepala sekolah, beliau menyampaikan bahwa Sekolah Menengah Atas Nusantara kota Jambi hanya mengikuti kurikulum terapan dari Dinas Pendidikan dan Kebudayaan kota Jambi, di mana bidang studi keagamaan dialokasikan satu kali pertemuan dalam satu minggu. Dan hal ini dianggap sangat kurang sekali dalam memenuhi program pemerintah yang menghendaki program pemberantasan buta aksara Alquran di berbagai lembaga pendidikan, khususnya kota Jambi. ${ }^{33}$

Pendapat tersebut di atas diperkuat wakil kepala sekolah bidang kurikulum yaitu Bapak Adrianus, S. Pd dalam sebuah wawancara dengan penulis mengatakan bahwa kesempatan untuk mengembangkan bimbingan baca Alquran di Sekolah Menengah Atas Nusantara kota Jambi tidak dapat dilaksanakan dengan maksimal sebagaimana diharapkan, karena pengalokasian waktu sebagaimana diatur dalam kurikulum diberikan hanya satu kali pertemuan dalam satu minggu,

33 Kepala Sekolah SMA Nusantara Jaya Kasumantri, Wawancara, 22 April 2013, Jambi, Catatan Lapangan, Alokasi waktu belajar mengajar bidang studi agama sebagaimana tertuang dalam kurikulum terapan Dinas Pendidikan dan Kebudayaan Kota Jambi di Sekolah Menengah Atas Nusantara, Jambi. 
sehingga proses bimbingan baca Alquran yang dilakukan guru PAI sangat terbatas sekali. Sementara itu, pembinaan peserta didik, khususnya mereka yang kurang mampu membaca Alquran membutuhkan banyak waktu dalam proses belajar mengajar baca Alquran hingga mereka dapat menguasai bagaimana membaca Alquran dengan baik dan fasih. ${ }^{34}$

Dalam pandangan penulis, kedua pendapat tersebut di atas adalah benar, namun demikian dapat dikatagorikan valid sebelum dilakukan studi lapangan. Oleh sebab itu, diperlukan data-data lapangan yang dapat menjawab keraguraguan mengenai preseden tersebut di atas. Adapun langkah yang diambil dalam membuktikan kebenaran informasi tersebut adalah dengan melakukan observasi di lapangan penelitian. Penulis kemudian melakukan pengamatan yang berkaitan dengan alokasi waktu pembelajaran bidang studi agama yang mengintegrasikan pembinaan baca Alquran. Dalam pengamatan tersebut, penulis memperoleh data lapangan yang menjelaskan bahwa sedikit sekali pengembangan-pengembangan yang dilakukan guru PAI Sekolah Menengah Atas Nusantara kota Jambi dalam pembinaan dan bimbingan baca Alquran. Hal ini tampak jelas dalam proses belajar mengajar, di mana guru harus menyajikan dua materi sekaligus, yakni materi keagamaan secara umum dan mengajarkan tata cara baca Alquran yang baik dan benar. Guru PAI dalam hal ini di satu sisi harus menyelesaikan sillabus materi keagamaan secara umum, namun di sisi lain ia harus memberikan bimbingan khususnya kepada peserta didik yang tidak memiliki kemampuan baca Alquran, sementara kegiatan belajar mengajar untuk materi ini diberikan hanya satu kali dalam seminggu. ${ }^{35}$

2. Kegiatan Ekstrakurikuler

Kegiatan ekstrakurikuler merupakan salah satu program unggulan di berbagai lembaga pendidikan dengan beberapa bentuk kegiatan non formal sebagai pendukung kegiatan intrakurikuler dalam mewujudkan visi dan misi sekolah. Kegiatan ini dimaksudkan untuk memberikan ruang yang cukup terhadap pengembangan kompetensi peserta didik, termasuk skill individu mereka dalam kerangka pembentukan karakter out put pendidikan. Kegiatan tersebut di atas umumnya terdiri dari aktivitas-aktivitas yang bersentuhan langsung dengan peserta didik dengan bimbingan guru-guru yang ditunjuk langsung oleh kepala sekolah.

Dalam konteks pemberantasan buta aksara Alquran, kegiatan ekstrakurikuler berperan penting dalam menfasilitasi mereka dalam melatih dan menekuni berbagai kecakapan yang diinginkan oleh peserta didik itu sendiri di luar kegiatan belajar mengajar formal. Kepala sekolah yang memiliki perhatian serius terhadap program pemerintah provinsi Jambi dalam hal pemberantasan buta aksara Alquran akan melakukan langkah-langkah progresif dalam mengelola seluruh aset sekolah sebagai pendukung utama dalam memberikan bimbingan baca Alquran. Karena penataan dan pengelolaan yang baik akan menghasilkan produk yang baik pula. Pengelolaan yang dilakukan kepala sekolah seharusnya

34 Wakabid Kurikulum SMA Nusantara Adrianus, Wawancara, 22 April 2013, Jambi, Catatan Lapangan, Minimnya alokasi waktu dalam proses pembinaan baca Alquran sebagaimana tertuang dalam kurikulum di Sekolah Menengah Atas Nusantara, Jambi.

35 Observasi, 25 April 2013 tentang kegiatan belajar mengajar Alquran di Sekolah Menengah Atas Nusantara kota Jambi 
mengkomunikasikan seluruh komponen sekolah dengan menerapkan prinsip perencanaan, pengorganisasian, penggerakan, pengawasan, serta disempurnakan dengan evaluasi sebagai bentuk follow up dari proses yang telah berlangsung.

Ketika persoalan tersebut dilakukan crosscheck dengan wakil kepala sekolah bidang kesiswaan melalui sebuah wawancara, wakil kepala sekolah bidang kesiswaan yang dalam hal ini adalah Bapak Drs. Bahtiar Nasution menjelaskan bahwa kepala sekolah berkomitmen serius terhadap program pemerintah provinsi Jambi dalam pemberantasan buta aksara Alquran. Menurutnya, kepala sekolah mengumpulkan seluruh wakil kepala di ruangannya kemudian menyampaikan beberapa program dan target yang akan dicapai guna mewujudkan program pemerintah. Pertemuan tersebut kemudian menghasilkan diskusi ringan membahas perihal langkah-langkah yang memungkinkan untuk diselenggarakan melalui kegiatan ekstrakurikuler. Hal ini mengingat bahwa peruntukan kegiatan ekstrakurikuler tidaklah semata-mata diperuntukkan untuk kegiatan bimbingan dan pembinaan baca Alquran, tetapi bagaimana seluruh program sekolah dapat diakomodir dalam kegiatan tersebut. Dan di antara beberapa kegiatan yang dapat dilakukan pembinaan baca Alquran dapat dilakukan melalui perayaan hari-hari besar Islam dan kegiatan-kegiatan dalam bulan suci ramadhan. ${ }^{36}$

Kedua pendapat tersebut diperkuat oleh pembina OSIS Sekolah Menengah Atas Nusantara kota Jambi yaitu Bapak Lukman, S.Pd dalam kesempatan wawancara dengan penulis mengatakan bahwa salah bentuk usaha yang dilakukan kepala sekolah dalam pembinaan baca Alquran siswa-siswi yang tidak memiliki kemampuan membaca Alquran dengan baik melalui manajemen persekolahan adalah dengan mengorganisir seluruh komponen sekolah dan mengarahkan mereka pada implementasi perencanaan sekolah yang telah ditetapkan sebelumnya untuk mewujudkan tujuan pendidikan. Ia menambahkan bahwa kepala sekolah bersifat proaktif dengan melakukan pendekatan kepada pihakpihak terkait di lingkungan Sekolah Menengah Atas Nusantara kota Jambi dan mempresentasikan beberapa agenda penting terkait dengan pembinaan baca Alquran di sekolah yang dipimpinnya. Dan secara praktik, kepala sekolah mendelegasikan beberapa kegiatan ekstrakurikuler kepada pembimbing OSIS untuk dapat mengisi agenda tersebut dengan pelatihan dan pembinaan baca al Qu'ran. ${ }^{37}$

Sebagai bentuk uji validitas data dari beberapa hasil wawancara tersebut di atas, penulis melakukan pengamatan lapangan dengan memperhatikan dan mengamati beberapa kegiatan yang dilaksanakan pada perayaan hari-hari besar Islam, khsususnya dalam peringatan Maulid Nabi Besar Muhammad Saw. Peringatan Maulid Nabi tersebut tidak hanya diisi dengan acara-acara seremonial yang bersifat pasif bagi seluruh peserta didik, tetapi dikembangkan melalui beberapa kegiatan keagamaan, di antaranya adalah dilakukannya beberapa lomba seperti lomba hafalan surat-surat pendek Alquran, di mana lomba ini setiap

${ }^{36}$ Wakabid Kesiswaan SMA Nusantara Bakhriar Nasution, Wawancara, 23 April 2013, Jambi, Catatan Lapangan, Bimbingan dan pembinaan baca Alquran melalui kegiatan ekstrakurikuler di Sekolah Menengah Atas Nusantara, Jambi.

37 Pembina OSIS SMA Nusantara Lukman, Wawancara, 23 April 2013, Jambi, Catatan Lapangan, Bimbingan baca Alquran melalui kegiatan ekstrakurikuler di Sekolah Menengah Atas Nusantara, Jambi. 
peserta mempersiapkan diri dengan latihan membaca dan menghafalkan Alquran sebelum mengikuti perlombaan. Dalam pengamatan tersebut tampak hirup pikuk para peserta lomba yang sedang menekuni bacaan Alquran dan menghafalkannya sesuai dengan petunjuk surat-surat Alquran yang diperlombakan. Dan kondisi ini semakin menarik ketika perombaan sedang dimulai, di mana masing-masing peserta yang mewakili kelas masing-masing tampak risau dan gelisah menunggu giliran tampil lantaran belum mengetahui pasti tentang surat-surat pendek yang mana saja yang akan diberikan dewan juri kepada yang bersangkutan. ${ }^{38}$ Dan adapun bentuk kegiatan pembinaan baca Alquran melalui kegiatan tadarus pada bulan suci ramadhan tidak dapat diobservasi langsung sebagaimana kegiatan lainnya disebabkan limit waktu penelitian yang terbatas sehingga tidak dapat dilakukan pengamatan sebagaimana hasil wawancara tersebut di atas, tetapi paling tidak dari beberapa informasi yang diperoleh di lapangan penelitian menunjukkan bahwa kegiatan tadarus pada bulan suci ramadhan merupakan salah bentuk upaya pemberantasan buta aksara di Sekolah Menengah Atas Nusantara kota Jambi.

\section{Pemberantasan Buta Aksaran Alquran di SMA Nusantara Kota Jambi}

\section{A. Kegiatan Kepala Sekolah Dalam Pemberantasan Buta Aksara Alquran}

Operasional sebuah lembaga pendidikan sebagai organisasi yang memiliki struktur formal akan tampak secara nyata apabila dikelola secara baik dan mengacu pada konsepsi dasar manajemen. Terdapat banyak indikator yang dapat dijadikan sebagai standar penilaian dalam melihat aktivitas organisasi tersebut, di antaranya adalah pengelolaan administrasi sekolah yang baik, adanya komunikasi yang baik di antara anggota organisasi dan indikator lainnya yang berkaitan dengan pembahasan tersebut di atas. Pengejawantahan atas teori-teori manajemen dapat diimplementasikan dalam berbagai kegiatan lembaga pendidikan, baik yang sifatnya formal maupun non formal. Dalam konteks kelembagaan, kepala sekolah merupakan top leader yang bertanggung jawab secara keseluruhan terhadap kegiatan pendidikan di lembaga pendidikan yang dipimpinnya. Maju dan mundurnya sebuah lembaga pendidikan banyak bergantung pada loyalitas dan keseriusan kepala sekolah dalam melakukan berbagai perubahan menuju pembaharuan di lembaga pendidikan tersebut. Meskipun demikian, tidak dipungkiri bahwa lembaga pendidikan dengan status yayasan memiliki tata aturan sendiri dalam hal birokrasi dan administrasi yang secara tidak langsung dapat mempengaruhi elektabilitas pendidikan yang sedang dan akan berlangsung. Dengan demikian, maka eksistensi sebuah lembaga pendidikan dengan ciri sebagaimana telah disebutkan di atas memiliki perbedaan yang cukup signifikan antara satu lembaga dengan lembagan pendidikan lainnya. Salah satu model perdebatan, misalnya tentang tata kelola keuangan, dimana biaya pendidikan tidak dapat diputuskan secara sepihak oleh kepala sekolah, akan tetapi dalam aturan yayasan harus berkomunikasi dengan pihak yayasan dalam menentukan berbagai kebijakan finasial. Tidak sedikit lembaga pendidikan yang gulung tikar disebabkan

38 Observasi, 8 April 2013 tentang pembinaan baca Alquran melalui kegiatan perlombaan dalam perayaan dan peringatan hari-hari besar Islam (PHBI) di Sekolah Menengah Atas Nusantara kota Jambi 
distorsi kebijakan, yang secara nyata berimplikasi pada proses pendidikan, dan kemudian mempengaruhi pula upaya-upaya seluruh komponen lembaga pendidikan tersebut dalam mewujudkan cita-cita dan tujuan pendidikan yang telah dibangun.

Pada bagian ini akan dipaparkan beberapa pembahasan yang menyangkut secara spesifik langkah-langkah progress kepala sekolah sebagai pimpinan tertinggi administrasi sekolah dalam mewujudkan visi, misi dan tujuan pendidikan yang telah dicanangkan sebelumnya. Fokus utama pembahasan ini mengacu pada upaya-upaya yang dilakukan kepala Sekolah Menengah Atas Nusantara kota Jambi dalam mengimplementasikan program pemerintah provinsi Jambi tentang pemberantasan buta aksara Alquran melalui kegiatan-kegiatan pendidikan di sekolah. Berdasarkan survey dan analisis data lapangan yang penulis lakukan, terdapat beberapa kegiatan yang dilakukan kepala sekolah dalam pembinaan baca Alquran di Sekolah Menengah Atas Nusantara dalam koridor pemberantasan buta aksara Alquran.

\section{Kegiatan Terstruktur}

Kegiatan formal secara administratif mengacu pada langkah-langkah kepala sekolah dalam mengembangan potensi baca Alquran di Sekolah Menengah Atas Nusantara kota Jambi melalui kegiatan belajar mengajar formal dalam bentuk klasikal. Secar manajerial, kepala sekolah memiliki peran yang sangat urgen dalam menentukan kebijakan pendidikan dalam rangka menumbuhkembangkan kegiatan baca Alquran, sehingga dengan kegiatan tersebut peserta didik yang tidak memiliki kompetensi baca Alquran yang baik dapat diberikan pembinaan dan bimbingan yang baik tentang tata cara baca Alquran melalui proses belajar mengajar formal di luar komponen kurikulum yang ada. Secara praksis, kepala sekolah tidak terjun langsung dalam pembinaan baca Alquran sebagaimana guru-guru yang mengajarkan Alquran dalam bentuk klasikal, tetapi secara administratif ia telah menjalankan perannya sebagai top leader dalam organisasi yang dipimpinnya. Fungsi leader dalam sebuah organisasi adalah bagaimana menggerakkan dan mengarahkan seluruh elemen sekolah agar dapat bersinergi dan berpartisipasi dalam pembinaan baca Alquran, khususnya bagi peserta didik yang kemampuan bacaan Alqurannya di bawah standar.

Untuk melihat akurasi statemen tersebut di atas, penulis melakukan klarifikasi melalui wawancara dengan kepala sekolah seputar kegiatan manajerial yang dilakukannya dalam pembinaan baca Alquran di Sekolah Menengah Atas Nusantara kota Jambi. Dalam kesempatan wawancara tersebut kepala sekolah menyampaikan bahwa dalam hal bimbingan dan pembinaan baca Alquran bagi siswa-siswi yang kurang mampu membaca Alquran tidak melakukan intervensi langsung terhadap aktivitas pembinaan yang dilakukan guru PAI, tetapi secara birokrasi struktural ia mengajukan program pengentasan buta aksara Alquran kepada guru pembimbing yang kemudian disampaikan dalam bentuk sharing informasi. Di antara program yang ditawarkan kepala sekolah adalah bimbingan tambahan terhadap siswa-siswi yang belum mampu membaca Alquran sama sekali di luar jadwal formal yang ada. Adapun mekanisme pelaksanaannya diserahkan sepenuhnya pada kebijakan guru PAI yang bersangkutan. Kegiatan lain yang memungkinkan dilakukan adalah melakukan komunikasi intensif kepada wali-wali murid yang anaknya belum bisa membaca Alquran tentang bagaimana 
memberikan bimbingan kepada mereka sehingga dapat membaca Alquran dengan baik. ${ }^{39}$

Ketika informasi tersebut di atas dicross check dengan guru PAI melalui sebuah wawancara dengan penulis, ia menjelaskan bahwa memang kepala sekolah telah mengkomunikasikannya, baik melalui pertemuan di ruang kepala sekolah maupun dalam bentuk rapat umum dewan guru. Namun menurutnya, bahwa agenda pemberian bimbingan tambahan di luar jadwal yang tersedia belum dilaksanakan dengan sempurna disebabkan keterbatasan waktu. Karena memang model bimbingan baca Alquran membutuhkan waktu yang cukup di luar agenda pendidikan formal sekolah, di mana seluruh aktivitas sekolah yang berkaitan dengan implementasi kurikulum telah tersusun dengan baik berdasarkan alokasi waktu masing-masing bidang studi. Lebih lanjut ia mengemukakan bahwa kadangkadang dilakukan bimbingan sederhana terhadap mereka yang sama sekali tidak mampu membaca Alquran dengan memberikan pengenalan huruf-huruf hijaiyah pada saat istirahat dari kegiatan belajar mengajar formal. Namun sifatnya sangat terbatas sekali dan tidak mampu mengakomodir seluruh peserta didik yang memiliki kemampuan baca Alquran yang sama. Maka dari itu, tidak banyak yang dapat dilakukan dalam mengimplementasikan program kepala sekolah sebagaimana telah disinggung di atas. Adapun model komunikasi kepala sekolah kepada orang tua yang memang anaknya tidak mampu membaca Alquran adalah sebuah langkah yang progresif, mengingat bahwa pembinaan baca Alquran peserta didik tidak semata-mata menjadi tangung jawab sepenuhnya pihak sekolah, tetapi harus melibatkan orang tua wali murid dalam rangka mencari solusi bagaimana membuat peserta didik yang bersangkutan mampu memposisikan diri mereka sejajar dengan peserta didik lainnya yang telah mampu membaca Alquran, meskipun belum sempurna sebagaimana yang diharapkan. ${ }^{40}$

Hal yang sama juga disampaikan wakil kepala sekolah bidang kurikulum yang dalam hal ini adalah Bapak Adrianus, S.Pd dalam kesempatan wawancara dengan penulis mengatakan bahwa agenda formal kepala sekolah dalam kaitannya dengan pembinaan dan bimbingan baca Alquran terhadap peserta didik yang tidak mampu membaca Alquran sama sekali dilakukan dalam bentuk individual approach, yakni agenda tersebut tidak dikomunikasikan kepada pihak-pihak terkait seperti guru PAI, wakil kepala madrasah di lingkungan Sekolah Menengah Atas Nusantara, dan beberapa orang tua wali murid secara tidak formal, dalam arti kata bahwa rancangan pemberantasan buta aksara Alquran disampaikan kepada mereka dalam bentuk dialogis sederhana dengan tanpa dilengkapi notulasi pertemuan, dan dalam pertemuan tersebut dijelaskan secara konkrit target-target dari proses yang ada dan tujuan yang akan dicapai, sehinga mereka dengan leluasa dapat menyampaikan dan mengemukakan pendapat terkait pembinaan bacaan

\footnotetext{
${ }^{39}$ Kepala Sekolah SMA Nusantara Jaya Kasumantri, Wawancara, 1 Juni 2013, Jambi, Catatan Lapangan, Kegiatan kepala sekolah dalam pengentasan buta aksara Alquran di Sekolah Menengah Atas Nusantara, Jambi.

40 Guru PAI SMA Nusantara M. Ridwan, Wawancara, 8 Juni 2013, Jambi, Catatan Lapangan, Pelibatan orang tua wali murid dalam agenda pemberantasan buta aksara Alquran di Sekolah Menengah Atas Nusantara, Jambi.
} 
Alquran di Sekolah Menengah Atas Nusantara kota Jambi. ${ }^{41}$ Informasi yang penulis peroleh dalam pengamatan tersebut adalah bahwa kepala sekolah dalam kesempatan tertentu terkadang melakukan komunikasi dengan beberapa orang seperti guru PAI, terkadang dengan wakil-wakil, dan bahkan kadang-kadang dengan orang tua wali murid. Penulis sendiri dalam kesempatan tersebut mendengarkan langsung apa-apa yang mereka perbincangkan, meskipun tidak mencapai pada suatu kesepakatan, atau bagaimana pelaksanaannya dan targettarget apa saja yang akan dicapai. Dan setelah selesainya pertemuan singkat tersebut, penulis langsung menemui wakil-wakil kepala di lingkungan Sekolah Menengah Atas Nusantara kota Jambi dan menanyakan perihal yang diperbincangkan bersama kepala sekolah sebagai pimpinan tertinggi di lembaga tersebut. Mereka pun menjelaskan bahwa tidak ada persoalan serius yang dibicarakan dalam kegiatan tersebut, hanya saja kepala sekolah mencoba menjelaskan bahwa pembinaan dan bimbingan baca Alquran terhadap siswa yang tidak bisa membaca Alquran sama sekali, bisa juga dilakukan melalui pendekatan orang tua wali murid, yakni dengan meminta mereka mencarikan guru private untuk mengajar anak-anak mereka tentang tata baca Alquran di rumah mereka masing-masing. Dengan model pendekatan orang tua wali murid ini, diharapkan peserta didik mendapatkan pengayaan bacaan Alquran yang tidak hanya didapatkan pada saat berada di lingkungan sekolah, tetapi didukung penuh oleh orang tua wali murid dengan menghadirkan guru pembimbing ketika mereka berada di rumah yang alokasi waktunya jauh lebih besar dibandingkan di sekolah. ${ }^{42}$

Pesantren kilat sebagaimana telah disinggung di atas merupakan salah satu wadah implementasi program pemberantasan buta aksara Alquran di lingkungan Sekolah Menengah Atas Nusantara kota Jambi, di samping kegiatan formal lainnya yang terintegrasi dalam materi agama dalam kurikulum sekolah. Pesantren kilat pada prinsipnya merupakan kegiatan semi formal sekolah, karena program pelaksanaannya telah disusun dalam draf kegiatan ramadhan, meskipun secara formal tidak termasuk dalam kurikulum sekolah. Kegiatan tersebut di atas dalam pandangan guru PAI sebagaimana diuraikan dalam sebuah wawancara dengan penulis bahwa pelaksanaan kegiatan pesantren kilat dapat memberikan ruang yang cukup terhadap peningkatan dan pengembangan kegiatan baca Alquran, karena keseluruhan materi yang disampaikan dalam kegiatan tersebut merupakan materi-materi keagamaan, termasuk pembinaan baca Alquran bagi peserta didik yang tidak memiliki kemampuan baca Alquran dengan baik. ${ }^{43}$

2. Kegiatan Tidak Testruktur

a. Pemberian Penghargaan

Pemberian penghargaan atau rewards kepada peserta didik yang berprestasi pada umumnya akan meningkat daya saing di antara mereka untuk

41 Wakabid Kurikulum SMA Nusantara Adrianus, Wawancara, 8 Juni 2013, Jambi, Catatan Lapangan, Upaya manajerial kepala sekolah dalam kaitannya dengan pemberantasan buta aksara di Sekolah Menengah Atas Nusantara, Jambi.

42 Observasi, 11 Juni 2013 tentang kegiatan kepala sekolah dalam pengentasan buta aksara Alquran di Sekolah Menengah Atas Nusantara kota Jambi

43 Wawancara, 22 Juni 2013 tentang kegiatan pesantren kilat sebagai sarana dalam pembinaan dan bimbingan baca Alquran di Sekolah Menengah Atas Nusantara kota Jambi 
memacu kreatifitas dan aktivitas untuk mencapai posisi 'the best' dalam kegiatan pendidikan di sekolah. Dalam berbagai teori sebagaimana dipaparkan para pakar bahwa penghargaan tidak selamanya diwujudkan dalam bentuk materi, tetapi dapat juga diberikan dalam bentuk non materi dan bersifat abstrak tergantung dari ketersediaan fasilitas dan kemampuan finansial sekolah. Pemberian penghargaan kepada peserta didik yang mengalami peningkatan kemampuan baca Alquran merupakan kegiatan lain yang dilakukan kepala sekolah dalam mengembangkan dan meningkatkan bacaan Alquran di Sekolah Menengah Atas Nusantara kota Jambi. Dan ketika hal tersebut di atas dikonfirmasikan kepada kepala sekolah, beliau menjelaskan dalam wawancaranya dengan penulis bahwa salah satu upaya yang dilakukannya dalam meningkatkan minat peserta didik belajar membaca Alquran adalah memberikan penghargaan kepada mereka yang mengalami peningkatan baca Alquran secara signifikan dari tidak bisa sama sekali hingga mampu membacanya dengan baik, meskipun belum sempurna menggunakan hukum tajwid dalam bacaannya. Lebih lanjut menurutnya, bahwa siswa-siswi yang telah melalui proses pembinaan dan bimbingan baca Alquran dan kemudian ada peningkatan secara positif untuk dicatat kemudian dilaporkan kepada kepala sekolah untuk ditindaklanjuti. ${ }^{44}$

Hal senada juga disampaikan wakil kepala bidang kesiswaan Sekolah Menengah Atas Nusantara kota Jambi, yaitu Bapak Drs. Bakhtiar Nasution dalam kesempatan wawancara dengan penulis, bahwa dalam rangka peningkatan dan pengembangan kegiatan belajar mengajar Alquran, terutama peningkatan kualitas bacaan Alquran, kepala sekolah dalam beberapa kesempatan memberikan penghargaan dalam bentuk hadiah buku agenda dan Alquran lengkap dengan terjemahnya kepada siswa-siswi yang mengalami peningkatan kemampuan baca Alquran. Dan hal ini dilakukannya sebagai bentuk apresiasi terhadap mereka yang mampu meningkatkan potensi diri dalam belajar Alquran. Lebih lanjut menurutnya, kepala sekolah sering memuji siswa-siswi yang mengalami peningkatan baca Alquran dengan cepat, dan kadang-kadang siswa yang bersangkutan dijadikan contoh bagi siswa-siswi yang lain dalam kaitannya dengan peningkatan dan pengembangan kemampuan baca Alquran di sekolah yang dipimpinnya. 45

Berdasarkan beberapa informasi yang diperoleh di atas, penulis merasa belum mendapatkan data akurat sebelum bertemu dan bertanya langsung kepada siswa-siswi yang pernah mendapat penghargaan dari kepala sekolah atas prestasi kemampuan meningkatkan bacaan Alquran. Penulis menemui salah seorang siswa bernama Andika Pratama Putra, siswa kelas XI IPS dan mewawancarainya seputar persoalan yang menjadi fokus penelitian, yakni ada tidaknya rewards yang diberikan kepada siswa-siswi yang mengalami perkembangan kemampuan bacaan Alquran dengan cepat. Dalam penuturan siswa tersebut, ia pernah mendapatkan hadiah dari sekolah berupa Alquran dan terjemahnya dengan sedikit uang pem

\footnotetext{
${ }^{44}$ Kepala Sekolah SMA Nusantara Jaya Kasumantri, Wawancara, 22 Juni 2013, Jambi, Catatan Lapangan, Pemberian rewards sebagai bentuk upaya yang dilakukan kepala sekolah dalam meningkatkan baca Alquran di Sekolah Menengah Atas Nusantara, Jambi.

45 Wakabid Kesiswaan SMA Nusantara Bakhtiar Nasution, Wawancara, 24 Juni 2013, Jambi, Catatan Lapangan, Bentuk apresiasi kepala sekolah terhadap siswa-siswi yang mengalami peningkatan baca Alquran dengan cepat di Sekolah Menengah Atas Nusantara, Jambi.
} 
binaan. Prestasi yang dimaknai dengan pemberian hadiah tersebut dirasakan oleh siswa yang bersangkutan sebagai pemicu motivasi diri agar selalu meningkatkan kemampuan belajar Alquran, dan kemampuan memahami kandungan Alquran. ${ }^{46}$

Untuk menguji validitas informasi yang diterima dari berbagai sumber informan, penulis melakukan observasi di lapangan penelitian terkait masalahmasalah yang dibahas dalam penelitian ini. Penulis mencoba mengamati Alquran dan terjemahnya yang dimiliki siswa yang dalam informasi sebelumnya mendapatkan apresiasi dari sekolah dalam bentuk hadiah. Dalam pengamatan tersebut, penulis mendapatkan informasi bahwa dalam Alquran tersebut terdapat tulisan yang menyatakan bahwa Alquran yang dimaksud merupakan kenangankenangan dari sekolah yang dibubuhi dengan cap stempel Sekolah Menengah Atas Nusantara kota Jambi. ${ }^{47}$

Berdasarkan data-data, baik yang bersumber dari beberapa informan maupun yang diperoleh langsung dari lapangan penelitian. Penulis kemudian menyimpulkan bahwa pemberian rewards kepada siswa-siswi yang mengalami peningkatan bacaan Alquran sebagai wujud apresiasi kepala sekolah terhadap prestasi yang dicapai siswa-siswi di Sekolah Menengah Atas Nusantara kota Jambi dalam kegiatan baca Alquran sebagai program lanjutan dari program pemerintah tentang pemberantasan buta aksara Alquran, merupakan serangkaian kegiatan kepala sekolah dalam pemberantasan buta aksara Alquran di Sekolah Menengah Atas Nusantara kota Jambi.

b. Pemberitan Motivasi

Pemberitan motivasi merupakan salah bentuk pembenahan internal peserta didik, dengan mengedepankan nilai-nilai moralitas bahwa segala sesuatu yang diberikan kepada mereka merupakan sebagai bentuk pendidikan mentalitas dalam mewujudkan peserta didik yang berkarakter. Memotivasi peserta didik dalam kerangka pendidikan karakter pada prinsipnya adalah upaya membentuk pribadi input pendidikan yang memiliki perbedaan karakter disebabkan perbedaan latar belakang pendidikan dan kemampuan daya tangkap terhadap materi pelajaran yang disampaikan kepada mereka. Dengan dengan karakter yang baik, akan menimbulkan sikap disiplin peserta didik yang baik, sehingga akan memudahkan mereka dalam menekuni kegiatan bimbingan dan pembinaan baca Alquran di Sekolah Menengah Atas Nusantara kota Jambi. Ketika persoalan tersebut dikonfirmasikan kepada kepala sekolah dalam sebuah wawancara dengan penulis, menyatakan bahwa pembinaan bacaan Alquran di sekolah yang dipimpinnya pada prinsipnya dikatagorikan dalam dua bentuk, yaitu katagori kegiatan terstruktur dan tidak terstruktur. Kegiatan terstruktur lebih mengedepankan aspek-aspek psikomotorik. Sementara kegiatan tidak terstruktur memberikan pengayaan terhadap kognitif dan afektif peserta didik. Lebih lanjut menurutnya, pemberian arahan dan motivasi kepada peserta didik secara tidak langsung akan meningkatkan pengetahuan teoritis mereka dalam memahami

\footnotetext{
${ }^{46}$ Siswa Kelas XI IPS SMA Nusantara Andika Pratama Putra, Wawancara, 24 Juni 2013, Jambi, Catatan Lapangan, Pemberian rewards kepada siswa-siswi yang mampu mencapai target dalam peningkatan baca Alquran di Sekolah Menengah Atas Nusantara, Jambi.

47 Observasi, 29 Juni 2013 tentang pemberian hadiah sebagai bentuk apresiasi atas prestasi yang diraih siswa dalam kegiatan belajar mengajar baca Alquran di Sekolah Menengah Atas Nusantara kota Jambi
} 
berbagai fenomena kegiatan belajar mengajar, terutama dalam kaitannya dengan peningkatan bacaan Alquran. Dengan demikian, maka pemenuhan aspek kognitif dan afektif peserta didik akan membantu mereka dalam proses implementasi dari teori-teori yang didapatkannya melalui kegiatan psikomotorik. Dan nilai positifnya akan tampak dalam peningkatan disiplin belajar mengajar di sekolah secara keseluruhan, termasuk kegiatan belajar mengajar Alquran. ${ }^{48}$

Pendapat tersebut di atas didukung oleh wakil kepala sekolah bidang kurikulum yang dalam hal ini adalah Bapak Adrianus, S. Pd. Dalam kesempatan wawancara dengan penulis menjelaskan bahwa dalam beberapa kesempatan upacara hari senin, kepala sekolah secara intens menyampaikan hal-hal yang berkenaan dengan peningkatan diri dalam memahami kandungan Alquran. Dan dengan pemahaman kandungan Alquran yang baik akan melahirkan peserta didik yang berkualitas dalam segala hal, terutama dalam sikap mental yang mencerminkan akhlakul karimah, dan semua harapan tersebut hanya bisa diperoleh apabila peserta didik memiliki kemampuan membaca dan memahami Alquran dengan baik dan sempurna. Sikap akhlakuk karimah yang sempurna akan mendewasakan peserta didik dalam berdisiplin, sehingga tatanan proses pendidikan akan berjalan dengan baik sesuai harapan yang diinginkan. ${ }^{49}$

Untuk membuktikan validitas informasi tersebut di atas, penulis menyempatkan diri mengikuti upacara pengibaran bendera pada hari senin yang diikuti oleh seluruh elemen sekolah dimana yang bertindak selaku pembina upacara adalah kepala sekolah langsung. Di sela-sela upacara yang sedang berlangsung, penulis melakukan pengamatan lansung tentang rangkaian amanah yang disampaikan kepala sekolah kepada peserta upacara. Informasi yang diperoleh dari hasil pengamatan terkait amanah yang disampaikan kepala sekolah terhimpun informasi bahwa kepala sekolah mengarahkan seluruh guru dan karyawan untuk selalu konsisten dalam menjalankan tugasnya masing-masing. Adapun arahannya kepada peserta didik, kepala sekolah menegaskan bahwa kegiatan pendidikan di Sekolah Menengah Atas Nusantara kota Jambi, mereka harus memiliki tiga kompetensi pendidikan, yaitu kognitif, afektif dan psikomotorik. Dalam kaitannya dengan pemberantasan buta aksara Alquran, kepala sekolah berpesan kepada peserta didik untuk selalu mengembangkan dan meningkatkan diri, terutama dalam memahami kandungan Alquran sebagai pedoman dan pegangan hidup. Kondisi ideal tersebut menurutnya tidak mudah diraih kecuali dengan memiliki kemampuan membaca Alquran. Di samping itu juga, ia menegaskan kepada mereka yang belum mampu membaca Alquran dengan baik dan fasih untuk lebih tekun belajar membaca Alquran di rumah, karena kesempatan belajar di rumah jauh lebih besar dibanding kesempatan yang dimiliki di sekolah. Dan dengan kemampuan membaca Alquran, diperkuat dengan kemampuan memahami kandungannya akan memberikan motivasi tersendiri

${ }^{48}$ Kepala Sekolah SMA Nusantara Jaya Kasumantri, Wawancara, 23 Juni 2013, Jambi, Catatan Lapangan, Kegiatan kepala sekolah dalam meningkatkan baca Alquran di Sekolah Menengah Atas Nusantara, Jambi.

49 Wakabid Kurikulum SMA Nusantara Adrianus, Wawancara, 23 Juni 2013, Jambi, Catatan Lapangan, Kegiatan tidak terstruktur yang dilakukan kepala sekolah dalam meningkatkan motivasi peserta didik dalam memahami Alquran di Sekolah Menengah Atas Nusantara, Jambi. 
pada diri peserta didik untuk tampil sebagai sosok siswa-siswi yang berakhlakul karimah. ${ }^{50}$

Pada kesempatan lain, penulis menindaklanjuti pengamatan tersebut di atas, dengan melakukan pemantauan dan pengamatan seputar hal-hal persuasif yang dilakukan kepala sekolah dalam memberikan pemahaman kepada peserta didik tentang pentingnya memahami kandungan Alquran. Penulis kemudian mulai mengamati pendekatan yang dilakukan kepala sekolah terhadap peserta didik yang secara faktual masih tergolong lamban dalam mengimplementasikan bacaan Alquran yang benar dan fasih. Hasil dari pengamatan tersebut membuahkan hasil, dimana pada saat istirahat belajar sebelum memasuki kegiatan belajar mengajar selanjutnya, kepala sekolah melakukan dialog sederhana dengan beberapa siswa di depan kelas tentang hasil yang dicapai siswa dalam kegiatan belajar membaca Alquran. Inti pembicaraan yang disampaikan cukup jelas, sehingga penulis dapat mendengarkan point-point penting yang disampaikan kepala sekolah. Dalam kesempatan dialog tersebut, kepala sekolah bertanya langsung kepada beberapa siswa tentang bagaimana perkembangan belajar Alquran, apakah ada peningkatan atau tidak. Dengan demikian, dapat penulis paparkan bahwa kepala sekolah dengan berbagai upaya melakukan pendekatan persuasif kepada peserta untuk mengetahui sejauh mana perkembangan hasil belajar siswa, dan disela-sela dialog tersebut kepala sekolah secara intens memberikan dorongan dan motivasi kepada mereka untuk tetap aktif mengikuti kegiatan sekolah, dan perlu disempurnakan kembali setelah kembali ke rumah masing-masing. ${ }^{51}$

Berdasarkan beberapa informasi yang penulis himpun dari hasil wawancara dan observasi tersebut di atas, penulis kemudian menyimpulkan bahwa pelaksanaan kegiatan pemberantasan buta aksara Alquran melalui bimbingan dan pembinaan bacaan Alquran di Sekolah Menengah Atas Nusantara kota Jambi dilaksanakan dalam dua katagori, yakni non verbal yang kemudian diimplementasikan dalam bentuk kegiatan belajar mengajar Alquran dalam materi agama Islam berbentuk klasikal formal, dan dalam bentuk verbal berupa penyampaian opini di depan masyarakat sekolah melalui kegiatan upacara bendera pada hari senin. Pemberian motivasi kepada peserta didik yang dilakukan kepala sekolah agar mereka tetap aktif mengikuti kegiatan belajar mengajar Alquran yang terintegrasi dalam mata pelajaran agama Islam dan atau melalui kegiatan ekstrakurikuler lainnya adalah sebuah pembuktian bahwa kepala Sekolah Menengah Atas Nusantara kota Jambi mendukung penuh program pemerintah dalam rangka pemberantasan buta aksara Alquran.

Pemberian motivasi secara terus menerus akan memberikan pemahaman yang baik bagi peserta dalam mengimplementasikan nilai-nilai yang terkandung dalam Alquran dalam kehidupan sehari-hari, terutama dalam membentuk miliu persekolahan yang didukung dengan kedisiplinan yang baik. Karena dengan disiplin yang baik, dapat dijadikan acuan dalam berbagai kegiatan sekolah, baik yang bersifat formal maupun non formal. Dalam kaitannya dengan manfaat utama

50 Observasi, 24 Juni 2013 tentang materi amanah yang disampaikan kepala sekolah dalam kaitannya dengan kegiatan belajar mengajar Alquran di Sekolah Menengah Atas Nusantara kota Jambi.

51 Obervasi, 22 Juni 2013 tentang motivasi kepala sekolah tentang peningkatan belajar mengajar Alquran di Sekolah Menengah Atas Nusantara kota Jambi 
disiplin sekolah sebagaimana dikemukakan Brown bahwa disiplin memiliki peran penting dan sangat strategis dalam proses pendidikan dan pembelajaran untuk mengajarkan hal-hal sebagai berikut:

1) Rasa hormat terhadap otoritas/ kewenangan; disiplin akan menyadarkan setiap siswa tentang kedudukannya, baik di kelas maupun di luar kelas, misalnya kedudukannya sebagai siswa yang harus hormat terhadap guru dan kepala sekolah.

2) Upaya untuk menanamkan kerja sama; disiplin dalam proses belajar mengajar dapat dijadikan sebagai upaya untuk menanamkan kerjasama, baik antara siswa, siswa dengan guru, maupun siswa dengan lingkungannya.

3) Kebutuhan untuk berorganisasi; disiplin dapat dijadikan sebagai upaya untuk menanamkan dalam diri setiap siswa mengenai kebutuhan berorganisasi.

4) Rasa hormat terhadap orang lain; dengan ada dan dijunjung tingginya disiplin dalam proses belajar mengajar, setiap siswa akan tahu dan memahami tentang hak dan kewajibannya, serta akan menghormati dan menghargai hak dan kewajiban orang lain.

5) Kebutuhan untuk melakukan hal yang tidak menyenangkan; dalam kehidupan selalu dijumpai hal yang menyenangkan dan yang tidak menyenangkan. Melalui disiplin siswa dipersiapkan untuk mampu menghadapi hal-hal yang kurang atau tidak menyenangkan dalam kehidupan pada umumnya dan dalam proses belajar mengajar pada khususnya.

6) Memperkenalkan contoh perilaku tidak disiplin. Dengan memberikan contoh perilaku yang tidak disiplin diharapkan siswa dapat menghindarinya atau dapat membedakan mana perilaku disiplin dan yang tidak disiplin. ${ }^{52}$

Teori-teori disiplin sebagaimana dikemukakan Brown di atas secara pragmatis dapat memberikan efek positif terhadap peserta didik dalam proses belajar mengajar di sekolah. Demikian juga dalam implementasinya pada kegiatan belajar mengajar baca Alquran yang diselenggarakan di Sekolah Menengah Atas Nusantara kota Jambi. Penerapan disiplin yang baik sebagai tindak lanjut dari pemberian motivasi peserta didik akan menanamkan pada diri mereka sikap kepatuhan dan ketaatan terhadap peraturan dan tata tertib sekolah. Dengan demikian, maka berimplikasi pada aktivitas belajar mengajar Alquran dalam ruang belajar yang dengan bimbingan guru PAI.

\section{B. Peran Guru PAI dalam Pemberantasan Buta Aksara Alquran}

Kegiatan belajar mengajar Alquran di sekolah-sekolah umum merupakan rangkaian materi pelajaran yang tidak independen, dalam arti kata bahwa materi tersebut diintegrasikan dalam bidang studi agama yang mencakup seluruh materi keagamaan. Sekolah Menengah Atas Nusantara kota Jambi sebagai dipaparkan pada pembahasan sebelumnya bahwa kegiatan belajar mengajar Alquran tidak berdiri sendiri atau diberikan porsi khusus dalam muatan kurikulum sebagaimana bidang studi lainnya, sehingga dengan demikian guru bidang studi mengalami kesulitan dalam manajemen waktu, dimana kegiatan belajar mengajar Alquran membutuhkan waktu yang cukup untuk memberikan peluang yang sama kepada seluruh peserta didik untuk mendalami bacaan Alquran.

${ }^{52} \mathrm{http} / / /$ arisandi.com/?p=995. Diakses 25 Juni 2013 
Perlu dikemukakan pada pembahasan ini bahwa tidak semua sekolahsekolah yang berafiliasi pada pendidikan umum memberikan porsi waktu khusus untuk kegiatan belajar mengajar Alquran. Sehingga memungkinkan sebuah kondisi, dimana peserta didik yang tidak memiliki kemampuan membaca Alquran tidak akan mendapat pembelajaran tata baca Alquran yang baik dan fasih. Kondisi sedemikian rupa bisa saja terjadi di berbagai lembaga pendidikan atau sekolahsekolah umum selama tidak mendapatkan perhatian dari kepala sekolah selaku pimpinan tertinggi. Dan hal ini adalah sebuah kewajaran karena memang kurikulum terapan Kementerian Pendidikan Nasional melalui Dinas Pendidikan setempat tidak memberikan peluang untuk kegiatan dimaksud, kegiatan belajar mengajar Alquran lebih dianggap sebagai kegiatan non formal yang diselenggarakan di luar jam pelajaran sekolah. Pandangan tersebut di atas pada prinsipnya keliru, karena secara defacto masyarakat Indonesia pada umunya menganut ajaran agama Islam yang lebih menekankan pengkajian terhadap Alquran. Bagaimana seseorang bisa memahami kandungan Alquran jika tidak memiliki dasar pengetahuan tentang Alquran, termasuk kemampuan membaca Alquran dengan baik dan fasih. Padahal dalam pandangan Muhammad Ali Ash Shaabuniy terdapat keutamaan dalam mempelajari dan mengajarkan Alquran, demikian pula keutamaan dalam membaca, memperhatikan dan pemantapannya. ${ }^{53}$

Pembahasan tentang peran guru PAI dalam pemberantasan buta aksara Alquran di sekolah secara eksplisit berkaitan juga program-program kepala sekolah terkait pembahasan yang menjadi fokus analisa penulis. Guru PAI disamping melaksanakan tugas profesionalitas, ia juga bertanggung jawab langsung kepada kepala sekolah tentang aktivitas yang dilaksanakannya. Dalam menjalankan perannya, guru PAI Sekolah Menengah Atas Nusantara kota Jambi melaksanakan tugas dan tanggung jawabnya dalam dua bentuk kegiatan, yaitu kegiatan belajar formal di kelas, dan di luar kelas. Kedua kegiatan tersebut akan dipaparkan pada pembahasan berikut ini.

1. Proses Belajar Mengajar di Kelas

Kegiatan belajar mengajar di ruang kelas dengan batasan waktu yang telah ditentukan sebagaimana diatur dalam jadwal pelajaran merupakan salah satu wadah belajar mengajar Alquran yang dilaksanakan guru PAI Sekolah Menengah Atas Nusantara kota Jambi. Meskipun belajar mengajar Alquran tidak memiliki alokasi waktu tersendiri sebagaimana bidang studi lainnya, tetapi paling tidak telah memberikan ruang untuk kegiatan pembinaan bacaan Alquran, khususnya bagi peserta didik yang tidak bisa membaca Alquran dengan baik dan fasih. Dalam proses belajar mengajar bidang studi agama, guru PAI melakukan bimbingan langsung kepada seluruh peserta didik dalam kelas dengan cara guru membacakan beberapa ayat Alquran yang berkaitan dengan materi ajar ke-Islaman, misalnya pembahasan pada suatu pertemuan tata muka disampaikan materi puasa. Setelah memberikan penjelasan tentang puasa, guru kemudian membacakan ayat Alquran yang berkenaan dengan puasa yang dalam hal ini adalah surat al Baqarah ayat 183. Kemudian diikuti seluruh siswa dengan memperhatikan cara bacanya dan makharikul huruf yang tepat sebagai diucapkan guru bidang studi. Kegaitan membaca ini dilakukan berulang kali sehingga siswa merasa akrab dengan bacaan

53 Muhammad Ali Ash Shaabuniy, Terj., Studi Ilmu Alquran, (Bandung: CV. Pustaka Setia, 2008), cet. ke- 10 , hlm. 16 
yang dipelajarinya. Setelah kegiatan ini selesai, guru bidang studi kemudian pindah ke tahap berikutnya, yaitu menuliskan ayat tersebut di papan tulis dan diteruskan dengan cara membacanya kata perkata secara kelompok dan individu.

Ketika hal tersebut dikonfirmasikan kepada guru PAI melalui sebuah wawancara, beliau kemudian menjelaskan bahwa terdapat perbedaan mengajar Alquran di sekolah dengan di rumah atau di masjid. Perbedaannya terletak pada kesempatan masing-masing siswa untuk mendapat bimbingan tata cara membaca Alquran. Dalam proses bimbingan membaca Alquran di kelas, prioritas bimbingan diberikan kepada siswa yang tidak bisa membaca Alquran, sementara yang lain mendengarkan secara seksama bacaan yang diajarkan oleh guru. Adapun di rumah dan di masjid, masing-masing peserta didik memiliki kesempatan yang sama dalam mengikuti bimbingan membaca Alquran, terlepas dari kemampuan membaca masing-masing peserta didik. Oleh sebab itu, sebelum dilaksanakan kegiatan belajar mengajar Alquran, terlebih dahulu dikelompokkan peserta didik sesuai dengan kemampuan masing-masing dalam membaca Alquran. Bagai kelompok yang tidak bisa membaca Alquran dengan baik, diberikan kesempatan bimbingan lebih banyak porsi waktunya dibanding mereka yang sudah bisa membaca Alquran. Proses bimbingan Alquran tidak difokuskan pada ayat-ayat tertentu dalam Alquran, tetapi diselaraskan dengan materi ajar dalam bidang studi agama Islam. Ayat Alquran yang terdapat dalam pembahasan tersebut kemudian dibaca secara berjama'ah sambil memberikan pembentulan bacaan kepada mereka yang makharijul hurufnya salah, langkah berikutnya adalah menuliskan ayat tersebut di papan tulis kemudian dibaca secara bertahap, yakni kata perkata sampai selesai ayat tersebut. Dalam kesempatan itu pula kadang-kadang siswa diminta tampil ke depan kelas untuk membaca ayat Alquran yang ada di papan tulis sambil membetulkan bacaan mereka yang salah. Di sela-sela kegiatan ini, diberikan juga pengayaan tentang kaidah bacaan Alquran, seperti cara membaca laam qomariyah (لام القمرية) dan laam syamsiyyah (لام الثمسية) dan beberapa materi lainnya. ${ }^{54}$

2. Kegiatan Yasinan di Musholla

Di samping kegiatan belajar mengajar Alquran secara formal sebagaimana telah dipaparkan di atas, Sekolah Menengah Atas Nusantara kota Jambi juga memberikan peluang kepada seluruh peserta didik untuk mengembangkan dan meningkatkan pemahaman dan pengetahuannya terhadap Alquran sebagai petunjuk dan pedoman bagi kaum muslimin melalui sebuah kegiatan semi formal yang lebih dikenal dengan kegiatan Yasinan pagi Jum'at bertempat di mushola sekolah. Kegiatan semi formal ini pada dasarnya bukanlah hal yang baru dalam dunia pendidikan, kegiatan ini sudah dikenal banyak di tengah-tengah masyarakat, di samping sebagai sarana beribadah, juga didaulat sebagai ajang menjalin dan mempererat tali silaturrahim di kalangan masyarakat tanpa memandang status dan strata sosial, dan atau pranata sosial yang terdapat di dalamnya. Kegiatan yasinan yang dilaksanakan di Sekolah Menengah Atas Nusantara kota Jambi dilaksanakan pada pagi hari Jum'at dari jam 07.15 - 08.00 WIB dan diikuti seluruh siswa-siswi yang beragama Islam dan didampingi oleh beberapa guru, dimana

${ }^{54}$ Guru PAI SMA Nusantara M. Ridwan, Wawancara, 25 Juni 2013, Jambi, Catatan Lapangan, Peran guru PAI dalam pembelajaran Alquran dalam rangka pemberantasan Alquran di Sekolah Menengah Atas Nusantara, Jambi. 
yang bertanggung jawab adalah wakil kepala sekolah bidang kesiswaan dan guru PAI.

Pemanfaatan moment kegiatan yasinan dan tahlilan sebagai wadah pemberian bimbingan kepada siswa-siswi yang kurang mampu membaca Alquran dengan baik dan fasih merupakan inisiatif guru PAI Sekolah Menengah Atas Nusantara kota Jambi. Kegiatan yasinan dan tahlilan dalam pandangan guru bidang studi PAI merupakan kesempatan penting untuk memberikan tambahan pemahaman dan pengayaan terhadap kompetensi baca Alquran bagi mereka yang dianggap lamban dalam menangkap materi ajar yang disampaikan guru dalam kegiatan belajar mengajar Alquran. Kondisi ini disadari betul oleh guru bidang studi bahwa alokasi waktu dalam pelajaran pendidikan agama Islam sangat terbatas sekali dalam pembinaan dan bimbingan baca Alquran. Ketika hal ini dikonfirmasikan kepada guru PAI melalui sebuah wawancara, beliau menyampaikan kepada penulis bahwa kepala sekolah dalam kapasitasnya sebagai top leader dan pimpinan administrasi sekolah hanya mengarahkan untuk diselenggarakannya pembacaan yasin dan tahlil pada hari Jum'at, dengan maksud untuk memberikan pemantapan rohani mereka dan membekali keterampilanketerampilan yang dibutuhkan masyarakat, agar kelak setelah menyelesaikan pendidikannya di sekolah ini mereka dapat mengamalkan ilmu pengetahuan yang mereka dapatkan di masyarakat. Adapun pemberian materi tambahan melalui bimbingan baca Alquran, meskipun bersifat sederhana merupakan upaya lain yang dilakukan guru PAI dalam mewujudkan program pemerintah tentang pemberantasan buta aksara Alquran. ${ }^{55}$

\section{Kendala yang Dihadapi dalam Pemberantasan Buta Aksara Alquran}

Kendala yang sering dihadapi dalam sebuah lembaga pendidikan meliputi kendal internal dan eksternal. Kendala internal merupakan persoalan-persoalan dalam lingkungan sekolah yang dapat menghambat pelaksanaan pendidikan di sekolah seperti keterbatasan fasilitas pendukung kegiatan belajar mengajar, faktor pembiayaan yang tidak mampu memenuhi kebutuhan dasar pendidikan, implementasi fungsi-fungsi manajemen yang tidak tepat sasaran, serta kendala internal lainnya. Adapun kendala eksternal dapat berupa latar belakang pendidikan peserta didik yang beraneka ragam yang berpengaruh pada proses belajar mengajar, stakeholder pendidikan yang kurang memberikan dukungan terhadap pelaksanaan pendidikan, dan kendala-kendala eksternal lainnya yang berpotensi menghambat proses pendidikan secara keseluruhan.

Sekolah Menengah Atas Nusantara kota Jambi sebagai salah satu lembaga pendidikan yang berlokasi di pusat perkotaan Jambi dalam implementasi programprogram pendidikan, menghadapi kendala-kendala sebagaimana sekolah-sekolah lainnya. Pada pembahasan ini, kendala-kendala yang dihadapi Sekolah Menengah Atas Nusantara kota Jambi akan dipaparkan dan dianalisa berdasarkan fakta-fakta faktual dari lapangan penelitian.

1. Kendala Internal

55 Guru PAI SMA Nusantara M. Ridwan, Wawancara, 18 Juni 2013, Jambi, Catatan Lapangan, Peran guru PAI dalam pembinaan dan bimbingan baca Alquran di Sekolah Menengah Atas Nusantara, Jambi. 
Kegiatan pemberantasan buta aksara Alquran di Sekolah Menengah Atas Nusantara kota Jambi sebagai program terapan sekolah dan wujud implementasi program pemerintah Provinsi Jambi tidak terlepas dari berbagai problematika, terutama dalam proses kegiatan belajar mengajar Alquran. Secara sederhana dapat penulis paparkan bahwa pada umumnya sekolah-sekolah yang berafilisasi pendidikan umum memiliki keterbatasan dalam kegiatan belajar mengajar Alquran. Kondisi ini sungguh jauh berbeda dengan model pendidikan di sekolahsekolah yang berafilisasi pendidikan Islam, seperti madrasah, pondok-pondok pesantren, dan lembaga pendidikan Islam lainnya. Hal fundamental yang menjadi kendala dalam kegiatan pemberantasan buta aksara Alquran di sekolah tersebut di atas mencakup beberapa sebagai berikut:

a. Kurikulum Sekolah

Sebagaimana dimaklumi bahwa kurikulum Kementerian Pendidikan Nasional yang diterapkan di berbagai pendidikan umum berbeda dengan kurikulum terapan Kementerian Agama. Dimana materi-materi yang terangkum dalam kurikulum Diknas lebih mengedepankan ilmu pengetahuan umum dibanding pengetahuan agama. Sehingga dalam tahap implementatif, sekolah tidak memiliki kewenangan untuk memberikan tambahan terhadap kurkulum yang disusun sesuai dengan petunjuk Diknas kota atau kabupaten tingkat dua. Pada kurikulum sekolah yang menerapkan kurikulum Diknas bidang studi agama diberikan dua jam pelajaran dalam satu minggu dengan komponen isi mencakup seluruh pengetahuan ke-Islaman.

Berdasarkan data-data tersebut di atas, penulis menyimpulkan bahwa keterbatasan waktu dalam kegiatan belajar mengajar Alquran merupakan kendala fundamental yang sulit ditemukan solusinya kecuali pihak-pihak yang kompeten dan memiliki wewenang sebagai decision maker memberikan dukungan penuh tehadap pelaksanaan kegiatan tersebut. Adapun pengembangan kurikulum yang selama ini dilakukan guru bidang studi belum menyentuh pada penambahan kuantitas pertemuan dalam kegiatan belajar mengajar Alquran. Adapun fungsifungsi manajemen pada fase ini mengalami stagnasi, dalam arti kata bahwa kepala sekolah tidak kuasa mengarahkan guru bidang studi pada kondisi tertentu yang bertentangan dengan kebijakan pemerintah itu sendiri dalam kaitannya dengan perubahan dan penambahan kurikulum sekolah. Padahal dalam teori manajemen kinerja sebagaimana dikemukakan E. Mulyasa bahwa manajemen kinerja kepemimpinan (kepala sekolah) adalah segala upaya yang dilakukan dan hasil yang dapat dicapai oleh kepala sekolah dalam mengimplementasikan manajemen berbasis sekolah di sekolahnya untuk mewujudkan tujuan pendidikan secara efektif dan efisien. Lebih lanjut ia menjelaskan bahwa manajemen kinerja kepala sekolah dapat dilihat berdasarkan beberapa kriteria, yaitu: mampu memberdayakan guru-guru untuk melaksanakan proses pembelajaran dengan baik, lancar, dan produktif, dapat menyelesaikan tugas dan pekerjaan sesuai dengan waktu yang telah ditetapkan, mampu menjalin hubungan yang harmonis dengan masyarakat sehingga dapat melibatkan mereka secara aktif dalam rangka mewujudkan tujuan sekolah dan pendidikan, berhasil menerapkan prinsip kepemimpinan yang sesuai dengan tingkat kedewasaan guru dan pegawai lain di 
sekolah, bekerja dengan tim manajemen, serta berhasil mewujudkan tujuan sekolah secara produktif sesuai dengan ketentuan yang telah ditetapkan. ${ }^{56}$

Dalam kaitannya dengan pembinaan dan bimbingan baca Alquran terhadap peserta didik, pada dasarnya untuk memberikan mereka dasar ilmu Alquran untuk sampai pada bagaimana memahami kandungan Alquran. Guru bidang studi PAI dalam praktiknya hanya mengajarkan tata cara membaca Alquran dan belum memberikan pengetahuan kepada peserta didik tentang bentuk qira'at dalam bacaan Alquran, padahal ilmu qira'at ini dapat memudahkan peserta didik dalam mengkaji kandungan Alquran. Sebagaimana dikemukakan Kadar M. Yusuf adanya perbedaan bentuk qira'at mempunyai faedah dan manfaat bagi mereka yang ingin belajar Alquran. ${ }^{57}$ Manfaat dan faedah tersebut dapat dikatagorikan dalam beberap hal sebagai berikut:

1) Meringkankan dan memudahkan umat Islam membaca Alquran, dimana suatu lafadz yang sulit diucapkan dapat diganti dengan lafadz yang mudah.

2) Menunjukkan betapa terjaganya kitab Allah ini dari perubahan dan penyimpangan.

3) Sebagai bukti kemukjizatan Alquran dari segi kepadatan maknanya, karena suatu qira'at menunjukkan suatu hukum syara' tertentu tanpa pengulangan lafadz.

4) Menjelaskan hal-hal yang mungkin belum jelas dalam qira'at yang lain.

Satu hal yang belum dilakukan guru bidang studi PAI Sekolah Menengah Atas Nusantara kota Jambi dalam kaitannya dengan penerapan fungsi-fungsi manajemen adalah monitoring. Fungsi monitoring dalam hal ini adalah bagaimana melakukan pemantauan yang tidak hanya terfokus pada proses belajar mengajar Alquran di sekolah tersebut, tetapi juga harus melakukan observasi eksternal dengan cara memantau kegiatan belajar mengajar Alquran di sekolah lain yang memiliki kesamaan visi dan misi dalam kaitannya dengan program pemberantasan buta aksara Alquran. Misalkan, melakukan koordinasi dengan guru-guru PAI di sekolah lain untuk mendapat informasi tentang bagaimana pelaksanaan kegiatan belajar mengajar Alquran. Tidak menutup kemungkinan ada hal-hal baru yang memungkinkan diterapkan di Sekolah Menengah Atas Nusantara kota Jambi, dengan cara berkoordinasi terlebih dahulu dengan kepala kepala sekolah sebagai laporan formal, agar dalam implementasinya mendapat dukungan penuh dari pihak-pihak terkait di sekolah yang bersangkutan.

\section{b. Minimnya Jumlah Guru PAI}

Sumber daya manusia yang handal merupakan basic resources dalam menciptakan pendidikan yang mencerdaskan. Sumber daya manusia yang dimaksud dalam tulisan ini adalah bagaimana kualitas anggota organisasi yang tergabung dalam sebuah lembaga pendidikan memiliki kompetensi yang baik sesuai dengan kebutuhan program sekolah. Misalkan, ketika sekolah akan menerapakan kurikulum yang baru 2013, maka sekolah harus memiliki sumber daya manusia yang memahami konsep-konsep teorits tentang kurikulum tersebut, di samping pemahaman terhadap diktum yang terdapat di dalamnya.

${ }^{56}$ E. Mulyasa, Op.Cit., hlm. 126

${ }^{57}$ Kadar M. Yusuf, Studi Alquran, (Jakarta: AMZAH, 2009), hlm. 52 
Demikian halnya dalam pemberantasan buta aksara Alquran, membutuhkan tenaga-tenaga profesional di bidangnya masing-masing dengan dukungan kompetensi keilmuan yang memadai. Lebih dari itu, kebutuhan sekolah terhadap tenaga yang profesional tidak hanya mengacu pada kualitas sumber daya manusianya, tetapi harus pula memperhatikan kuantitasnya. Lembaga pendidikan dengan jumlah siswa-siswinya yang relatif banyak membutuhkan tenaga profesional banyak pula sesuai dengan prosentase analisis kebutuhan. Namun kondisi ini sesungguhnya berbeda ketika perhatian kita diarahkan pada Sekolah Menengah Atas Nusantara kota Jambi. Sekolah dengan jumlah siswa mencapai 434 orang dengan tenaga pengajar bidang studi agama Islam satu orang guru adalah sebuah ketidakwajaran. Bagaimana seorang guru dapat memenuhi kebutuhan dasar ilmu pengetahuan agama siswa dengan jumlah yang cukup besar, maka hal ini menjadi kendala tersendiri bagai guru bidang studi PAI dalam proses belajar mengajar.

Untuk mendapatkan informasi yang akurat, penulis mewawancarai langsung kepala Sekolah Menengah Atas Nusantara kota Jambi terkait jumlah tenaga pengajar bidang agama Islam. Dalam kesempatan wawancara tersebut kepala sekolah menyampaikan kepada penulis bahwa Sekolah Menengah Atas Nusantara kota Jambi hanya memiliki satu orang guru bidang studi agama Islam. Menurut pengakuannya, dengan satu orang guru bidang studi agama Islam tidak akan mampu memberikan pembelajaran yang maksimal, terutama dalam kegiatan belajar mengajar Alquran. Keterbatasan tenaga pengajar bidang studi agama Islam ini pada dasarnya keterbatasan sekolah dalam melakukan manajerial rekrutmen guru ditinjau dari perspektif administrasi sekolah. Seharusnya sekolah dengan jumlah siswa mencapai 434 memiliki guru bidang studi PAI minimal dua orang. Namun demikian, sudah menjadi ketetapan sejak awal tahun ajaran baru dimana materi agama Islam secara administratif diarahkan pada pemberian penyuluhan kepada peserta didik tentang agama Islam. Namun seiring dengan perkembangan zaman, ditambah program pemberantasan buta aksara Alquran yang dicanangkan pemerintah, maka seharusnya dilakukan pengkajian ulang tentang kapasitas tenaga pengajar bidang studi agama Islam, apakah dilakukan penambahan guru bidang studi agama Islam, atau tetap pada posisi awal, yakni cukup dengan satu guru bidang studi saja. ${ }^{58}$

Secara teoritis, khususnya dalam pengajaran al Qur'an yang berkenaan dengan aspek bacaan aksara al Qur'an, memiliki metode dan strategi tertentu. Dalam buku Pedoman Pengajian Al Qur'an yang diterbitkan Kementerian Agama, menyebutkan empat metode yang digunakan oleh sebagian guru dalam mengajarkan aksara al Qur'an, yakni: Metode tarkibiyah (metode sintetik), yakni metode pengajaran membaca dimulai dari mengenal huruf hijaiyyah. Kemudian diberi tanda baca/harakat, lalu disusun menjadi kalimat (kata), kemudian dirangkaian dalam suatu jumlah (kalimat). Kemudian metode shautiyyah (metode bunyi), yakni dimulai dengan bunyi huruf aksara, bukan nama-nama huruf contoh: Aa-Ba-Ta dst. Dari bunyi ini disusun menjadi satu kata yang kemudian menjadi kata atau kalimat yang teratur. Selanjutnya metode musyafahah (metode meniru),

58 Kepala Sekolah SMA Nusantara Jaya Kasumantri, Wawancara, 24 Juni 2013, Jambi, Catatan Lapangan, Keterbatasan guru bidang studi agama Islam di Sekolah Menengah Atas Nusantara, Jambi. 
adalah meniru dari mulut ke mulut atau mengikuti bacaan seorang guru, sampai hafal. Setelah itu, baru diperkenalkan beberapa buah huruf beserta tanda baca/harakat dari kata-kata atau kalimat yang dibacanya itu. Dan metode Jaami'ah (metode campuran), adalah metode yang menggabungkan metode-metode tersebut di atas $(1,2,3)$ dengan jalan mengambil kebaikan-kebaikannya disesuaikan dengan situasi dan kondisi. Di samping itu, ditemukan pula berbagai metode lain dalam literatur yang berbeda, yang kesemuanya saling melengkapi. Metode-metode yang dimaksud mencakup metode al Barqi, adalah metode mengembangkan pengajaran baca tulis dalam berbagai bahasa dengan menggunakan pendekatan global yang bersifat struktural, analitis dan sistesis (SAS), yang dalam hal ini terbagi dua yaitu SAS murni, adalah penggunaan bahasa antara tulisan dengan bunyi tidak sama, seperti: one, two, three. Jadi SAS murni ini cocok dengan pelajaran bahasa Inggris. Dan semi SAS, adalah penggunaan struktur kata atau kalimat, yang tidak mengikutkan bunyi mati sukun atau kalimat, yang tidak mengikutkan bunyi mati atau sukun, umpamanya: jalasa, kataba, sehingga penyusunan bahasa Arab dan Indonesia lebih cocok menggunakan semi SAS. Selanjutnya metode hattaiyyah, yaitu metode belajar al Qur'an dengan pengenalan huruf, tanda baca, melalui huruf latin. Awal pengenalan huruf al Qur'an dimulai dengan Lam, bukan Alif. Huruf al Qur'an yang sulit diajarkan, paling akhir diberikan, sebab agak susah persamaan lainnya. Dan metode iqra', yakni metode belajar al Qur'an dengan menggunakan sistem cara belajar siswa aktif (CBSA), guru sebagai penyimak saja, privat dengan penyimakan secara seorang demi seorang, asistensi dimana peserta didik yang lebih tinggi pelajarannya diharapkan membantu menyimak santri lain. Kemudian dalam menyampaikan metode-metode pengajaran sebagaimana yang telah disebutkan memerlukan beberapa strategi, misalnya persuasif dengan cara mengusahakan peserta didik belajar al Qur'an dengan keasadaran yang tinggi, sehingga mereka membaca al Qur'an merupakan suatu kebutuhan. Sugestif, yakni anak didik diberikan dorongan dari sisi lain (bukan kesadaran) tetapi berupa hadiah atau penghargaan, rekreatif, dan dijaga agar dorongan berupa hadiah dan semacamnya tidak menjadi motivasi utama dalam belajar al Qur'an. Campuran, yakni strategi persuasif dan sugestif dapat dipadukan dalam kondisi tertentu. ${ }^{59}$

2. Kendala Eksternal

a. Latar Belakang Pendidikan Siswa

Latar belakang pendidikan peserta didik menjadi perhatian tersendiri pada saat pengkajian difokuskan pada hubungan relasi antara proses dan hasil yang akan dicapai. Biografis peserta didik yang berbeda dalam tiga ranah, baik kognitif, afektif dan psikomotorik akan berdampak pada tingkat pemahaman dan kualitas keberterimaan informasi dan pesan baru dari materi pelajaran yang disampaikan kepada mereka. Latar belakang pendidikan yang berbeda-beda sedikit banyaknya berpengaruh pada tingkat pemahaman dan daya nalar terhadap materi-materi yang disampaikan kepada mereka. Perbedaan mendasar pada latar belakang pendidikan peserta didik berpengaruh pada proses belajar mengajar,

${ }^{59} \mathrm{http}: / /$ www.artikelbagus.com/2011/04/peranan-pemerintah-dalam-rangka.html. Diakses tanggal 3 Juni 2013 
sehingga membutuhkan penanganan yang optimal dari guru bidang studi dalam mengejar target capaian yang telah dirumuskan sebelumnya.

Dalam kondisi normal, sekolah yang memiliki input pendidikan yang baik karena melakukan seleksi ketat dalam penerimaan siswa baru, akan berdampak pada kegiatan pendidikan yang diselenggarakan di lembaga pendidikan yang bersangkutan. Kondisi ini dapat memberikan kemudahan kepada kepala sekolah beserta seluruh jajarannya dalam menjalankan aktivitas organisasi dalam rangka mewujudkan cita-cita dan tujuan yang telah dirumuskan. Namun berbeda halnya ketika sebuah lembaga pendidikan dengan komunitas input yang serba kekurangan, terutama dari aspek kualitas dan kompetensi masing-masing peserta didik. Maka dengan demikian, proses pendidikan yang diselenggarakan menjadi tidak balance antara input dan out put. Di satu sisi mengejar kualitas out put yang baik, namun di sisi lain kondisi input yang serba kekurangan. Salah satu faktor yang dapat menyebabkan kondisi ini adalah perbedaan latar belakang pendidikan peserta didik yang cukup signifikan. Meskipun diakui bahwa tingginya tingkat perbedaan latar belakang pendidikan peserta didik tidak dapat dijadikan sebagai acuan dasar dalam penilai keberhasilan sebuah lembaga pendidikan.

Persoalan tersebut di atas dalam konteks pemberantasan buta aksara Alquran merupakan salah satu persoalan prinsip yang dialami Sekolah Menengah Atas Nusantara kota Jambi. Ketika hal tersebut dikonfirmasikan dengan kepala sekolah yang dalam hal ini adalah Bapak Jaya Kasumantri, S. Pd melalui sebuah wawancara mengatakan bahwa salah satu kendala yang tidak dapat dihindari ketika fokus pembahasan diarahkan pada pemberantasan buta aksara Alquran. Kondisi sosiologis dan biografis peserta didik di sekolah ini menampilkan corak perbedan yang cukup siginifikan dari kualitas kemampuan baca Alquran. Untuk katagori siswa yang tidak bisa sama sekali membaca Alquran terdapat 32 orang, akan tetapi 377 siswa belum seluruhnya mampu membaca Alquran dengan fasih dan lancar. Lebih lanjut menurutnya, 377 siswa tersebut tidak pula memiliki kemampuan baca Alquran dengan fasih dan lancar, secara umum mereka hanya mampu membaca dengan katagori tidak lancar, sehingga menjadi kendala tersendiri pada saat belajar mengajar Alquran sedang berlangsung. Hal ini memang diakui bahwa kemampuan baca tulis Alquran bukan termasuk persyaratan dalam penerimaan siswa baru di sekolah ini. Sehingga dalam proses rekrutmen peserta didik, kemampuan baca tulis Alquran sedikit diabaikan disebabkan komponen kurikulum yang tidak mengarahkan proses tersebut ke arah mutualitas baca Alquran yang baik dan fasih. Sehingga dalam implementasi kurikulum, kegiatan pemberantasan buta aksara Alquran cukup diintegrasikan dalam bidang studi agama Islam dan muatan lokal. ${ }^{60}$

Hal yang sama juga disampaikan Ibu Pauwani selaku kepala tata usaha di lingkungan Sekolah Menengah Atas Nusantara kota Jambi melalui sebuah wawancara dengan penulis, bahwa siswa-siswi yang mengikuti pendidikan di sekolah ini berlatar belakang dari beberapa sekolah yang berbeda. Di antara mereka berasal dari Sekolah Menengah Pertama (SMP), dan Madrasah Tsanawiyah (MTs). Pada umumnya mereka berasal dari Sekolah Menengah Pertam (SMP)

${ }^{60}$ Kepala Sekolah SMA Nusantara Jaya Kasumantri, Wawancara, 11 Juni 2013, Jambi, Catatan Lapangan, Kendala-kendala yang dihadapi dalam kegiatan pemberantasan buta aksara Alquran di Sekolah Menengah Atas Nusantara, Jambi. 
dengan kemampuan membaca Alquran yang masih sangat jauh dari kesempurnaan, dan sedikit sekali yang berasal dari Madrasah Tsanawiyah (MTs) dan atau pernah mengenyam pendidikan di madrasah. Terkait dengan kualitas mereka dalam membaca Alquran, pada prinsipnya kemampuan baca Alquran tidak termasuk sebagai persyaratan tes masuk ke sekolah ini. Sehingga kegiatan belajar mengajar Alquran menjadi wewenang dan tanggung jawab guru PAI sesuai tugas dan tanggung jawab yang telah ditetapkan. ${ }^{61}$

b. Kurangnya Partisipasi Orang Tua (Wali Murid)

Program pemberantasan buta aksara sebagaimana dicanangkan pemerintah pada prinsipnya bukanlah menjadi tanggung jawab pemerintah secara sepihak, termasuk dalam hal ini lembaga-lembaga pendidikan yang merupakan wadah implementasi kegiatan belajar mengajar secara keseluruhan. Tetapi menjadi tanggung jawab seluruh stakeholder pendidikan, terutama para orang tua wali murid. Peran aktif orang tua akan memberikan dampak positif terhadap program tersebut di atas, di mana kontribusi yang mereka berikan dalam rangka mewujudkan harapan bersama guna menciptakan lingkungan persekolahan yang terbebas dari kebutaaksaraan adalah sebuah realitas yang harus menjadi pehatian dari para orang tua wali murid.

Sangat dilematis sekali apabila para orang tua wali murid ikhlas mengeluarkan biaya yang begitu besar untuk membiayai anak-anak mereka dalam mengikuti berbagai kursus dan private dalam pelajaran tertentu seperti kursus bahasa Inggris, matematika, kimia dan lain sebagainya. Namun pada sisi lain, merasa keberatan mengeluarkan sejumlah uang untuk membayar honorarium para guru ngaji, baik di perkampungan maupun di kota-kota besar, terutama di kota Jambi. Padahal nilai-nilai religiusitas yang terkandung dalam Alquran akan memberikan pencerahan mentalitas peserta didik menuju akhlakul karimah sebagai basis utama dalam kegiatan pendidikan di berbagai lembaga pendidikan. Fenomena tersebut di atas dalam pandangan penulis lebih disebabkan karena world view para orang tua yang lebih terfokus pada pasar bebas global yang menghendaki ketatnya persaingan, sehingga menggiring out put pendidikan pada suatu kondisi di mana mereka harus mempersiapkan skill individu dan berbagai keterampilan untuk dapat masuk dalam dunia pasar dan memiliki nilai jual dalam kancah persaingan global.

Persoalan tersebut di atas dalam perspektif dunia kerja adalah sebuah kewajaran, namun akan mengikis nilai keadilan apabila tidak diimbangi dengan pencerahan aspek mentalitas yang sesungguhnya berdampak pada pembentukan moralitas sebagai basis utama pendidikan. Menarik untuk dikemukakan dalam tulisan ini bahwa harus ada keseimbangan antara tiga komponen dasar prinsip pendidikan yang melekat pada diri peserta didik yang terdiri dari kognitif, afektif, dan psikomotorik. Unsur-unsur kognitif dan psikomotorik adalah pemenuhan skill individu dengan berbagai keahlian dan ketermapilan, sementara unsur afektif harus pula disempurnakan dengan muatan-muatan religiusitas yang mengakar pada pembentukan moral dan akhlakul karimah.

61 Kepala TU SMA Nusantara Pauwani, Wawancara, 11 Juni 2012, Jambi, Catatan Lapangan, Kendala-kendala yang dihadapi dalam kegiatan pemberantasan buta aksara Alquran di Sekolah Menengah Atas Nusantara, Jambi. 
Dalam kaitannya dengan peran aktif para orang tua wali murid di Sekolah Menengah Atas Nusantara kota Jambi, terutama pada implementasi program pemberantasan buta aksara Alquran, sesungguhnya para orang tua wali murid harus memberikan dukungan penuh dalam perwujudan program tersebut. Partisipasi para orang tua wali murid di sekolah ini tampaknya tidak begitu dominan dalam mengarahkan anak-anak mereka menekuni pengkajian terhadap Alquran. Para orang tua wali murid kurang mendorong putra-putri mereka memperdalam pengetahuan mereka terhadap Alquran. Salah satu indikator yang mungkin diungkapkan dalam tulisan ini adalah para orang tua wali murid tidak memberikan bimbingan baca Alquran kepada anak-anak setelah mereka kembali ke rumah dan atau memberikan waktu dan ruang kepada mereka untuk mengikuti berbagai kegiatan pengajian Alquran, baik yang dilaksanakan di rumah mereka sendiri dan atau di masjid. Realitas ini terungkap setelah peserta didik kembali belajar sebagaimana mestinya di sekolah, dan belum ada perkembangan yang cukup signifikan tentang peningkatan bacaan Alquran.

Ketika persoalan tersebut di atas dikonfirmasikan dengan guru PAI, yaitu Bapak M. Ridwan, S.Ag dalam sebuah wawancara, beliau mengatakan bahwa dukungan para orang tua wali murid terhadap program pemberantasan buta aksara Alquran masih sangat kurang. Hal ini dapat dilihat dari bentuk peran aktif mereka dalam memberikan dorongan kepada anak-anak mereka untuk meningkatkan belajar membaca Alquran di rumah mereka masing-masing belum terlaksana dengan baik. Ketika ditanyakan kepada siswa-siswi di kelas, apakah orang tua mereka memberikan bimbingan langsung baca Alquran di rumah dan atau mendatangkan guru private khusus (guru ngaji) untuk membimbing mereka belajar baca Alquran di rumah. Secara umum peserta didik memberikan jawaban bahwa orang tua mereka belum pernah membimbing mereka membaca Alquran di rumah dan atau mendatangkan guru ngaji khusus untuk mengajarkan tata cara membaca Alquran yang baik dan fasih. ${ }^{62}$

Informasi tersebut di atas dalam pandangan penulis belum memberikan jawaban yang konkrit untuk melihat bagaiaman peran aktif para orang tua wali murid dalam program pemberantasan buta aksara Alquran. Oleh sebab itu, penulis kembali mewawancarai salah seorang siswi kelas XI yang bernama Oktaviani untuk menggali informasi yang lebih akurat tetang partisipasi para orang tua wali murid dalam kegiatan pembinaan dan bimbingan baca Alquran di rumah. Pada kesempatan wawancara tersebut, siswi yang bersangkutan mengatakan bahwa orang tuanya belum pernah memberikan bimbingan atau mengajarinya membaca Alquran di rumah. Kegiatan membaca Alquran hanya diikuti bersama temantemannya pada bulan suci ramadhan, tepatnya dalam kegiatan tadarus bersama di masjid, dan kegiatan ini pun diikuti tidak setiap hari, tergantung dari kesempatan yang dimilikinya. Lebih lanjut ia menjelaskan bahwa hal yang sama dialami temantemannya, baik yang berasal dari satu sekolah maupun dari sekolah lain. ${ }^{63}$

${ }^{62}$ Guru PAI SMA Nusantara M. Ridwan, Wawancara, 13 Juni 2013, Jambi, Catatan Lapangan, Partisipasi orang tua wali murid dalam kegiatan pemberantasan buta aksara Alquran di Sekolah Menengah Atas Nusantara, Jambi.

63 Siswi Kelas XI SMA Nusantara Oktaviani, Wawancara, 14 Juni 2013, Jambi, Catatan Lapangan, Partisipasi orang tua wali murid dalam kegiatan pemberantasan buta aksara Alquran di Sekolah Menengah Atas Nusantara, Jambi. 


\section{Upaya-Upaya yang Dilakukan dalam Mengatasi Kendala dalam Kaitannya dengan Pemberantasan Buta Aksara Alquran}

Kendala-kendala sebagaimana telah dipaparkan di atas, sesungguhnya tidak dibiarkan begitu saja tanpa dilakukan berbagai upaya-upaya konstruktif, Sekolah Menengah Atas Nusantara kota Jambi pada tahun pelajaran 2012-2013 melalui kepala sekolah sebagai pmpinan tertinggi telah melakukan berbagai terobosan dan langkah-langkah progressif guna mewujudkan lembaga pendidikan yang bebas dari buta aksara Alquran. Meskipun diakui bahwa upaya-upaya tersebut belum mampu mencapai target maksimal, disebabkan berbagai persoalan mendasar seperti kurikulum terapan yang tidak memungkinkan dilakukan perubahan secara mendasar terhadap domain muatannya.

Langkah-langkah konstruktif yang dilakukan kepala sekolah dalam kaitannya dengan antisipasi keterbatasan kurikulum yang kurang memberi ruang terhadap pelaksanaan program pemberantasan buta aksara Alquran adalah dengan melakukan pendekatan kepada seluruh majelis guru. Pendekatan tersebut dimaksudkan untuk memberikan arahan kepada mereka dalam hal materi ajar yang mereka sampaikan. Untuk melihat bagaimana peran aktif kepala sekolah dalam mengatasi masalah yang berkaitan dengan pengembangan kurikulum, penulis melakukan wawancara langsung dengan kepala sekolah. Dalam wawancara tersebut, kepala sekolah menyampaikan bahwa kurikulum yang sudah ada dan telah diterapkan di sekolah ini tidak mungkin dirubah, yang dilakukan hanyalah pengembangan selama tidak mengurangi kuantitas dan kualitasnya. Lebih lanjut ia menegaskan bahwa pendekatan yang dilakukan dengan para majelis guru melalui berbagai kesempatan, baik itu dalam bentuk rapat, musyawarah dan atau dengan model personal approach, bahwa materi ajar yang disampaikan semampu mungkin dikaitkan dengan nilai-nilai Islam, terutama yang berkaitan dengan alam dan kehidupan manusia, sehingga materi tersebut dikaitkan dengan ayat-ayat Alquran dan atau hadits Nabi Muhammad Saw. Dengan demikian maka nuansa kegiatan belajar mengajar lebih konstruktif, dimana guru masing-masing bidang studi secara sederhana menyampaikan ayat Alquran atau hadits Nabi dan dalam praktiknya meminta peserta didik melafalkan ayat-ayat Alquran atau hadits tersebut. Kegiatan belajar mengajar sedemikian rupa dalam konteks pembelajaran bahasa Arab telah mengaplikasikan dua bentuk kecapakan bahasa, yaitu kecakapan mendengar (مهارة الإستماع) dan kecakapan membaca ( إع مهارة (القراءة. Kegitan ini telah pula mengajarkan peserta didik bagaimana melafalkan kata-kata berbahasa Arab dengan baik, dan juga memberikan pengayaan berbentuk latihan mendengar kata-kata berbahasa Arab yang kemudian diungkapkan melalui lisan. ${ }^{64}$

Pendapat tersebut di atas kemudian diperkuat AD dalam sebuah wawancara dengan penulis mengatakan bahwa garis-garis besar pedoman pelaksanaan kurikulum merupakan acuan dasar dalam kegiatan belajar mengajar, sehingga seluruh majelis guru diarahkan untuk membuat perangkat pembelajaran yang mengacu pada pedoman tersebut. Kepala sekolah selaku pimpinan

${ }^{64}$ Kepala Sekolah SMA Nusantara Jaya Kasumantri, Wawancara, 8 Juni 2013, Jambi, Catatan Lapangan, Upaya-upaya dilakukan dalam mengatasi kendalai yang dihadapi dalam kegiatan pemberantasan buta aksara Alquran di Sekolah Menengah Atas Nusantara, Jambi. 
administrasi menjalankan perannya selalu pimpinan dengan mengorganisir seluruh anggota organisasi Sekolah Menengah Atas Nusantara kota Jambi, khususnya majelis guru, agar dalam proses belajar mengajar, seluruh majelis guru dapat mengkombinasikan materi ajar melalui pembelajaran kontekstual, dengan cara mengkaitkan materi-materi yang akan disampaikan kepada peserta didik dengan lingkungan belajar mereka. Kemudian diperkaya dengan memasukkan ayat-ayat Alquran dan hadist Nabi yang terkait dengan materi ajar dan disampaikan di depan kelas. Kegiatan ini dimaksudkan untuk memberikan wawasan yang luas bagi peserta didik, sehingga ketika mereka belajar fisika tentang tata surya misalnya, maka asumsi dasarnya adalah bahwa bukan planetplanet tata surya yang berputar saling mengelilingi, tetapi ada kekuatan transendental di balik itu semua, yakni Dzat Allah SWT. Maka secara otomatis ketika materi yang disampaikan di depan kelas dikaitkan dengan ayat-ayat Alquran dan atau hadits Nabi, secara tidak langsung dilakukan kegiatan pelafalan ayat-ayat Alquran, dan atau guru bidang studi membacakan ayat Alquran sementara itu peserta didik mendengarkan bacaan guru. 65

Hal yang sama juga disampaikan salah seorang siswa kelas X, yaitu Rudi Rolanda dalam kesempatan wawancara dengan penulis mengatakan bahwa kadang-kadang dalam belajar fisika, terutama materi yang bersinggungan langsung dengan alam semesta, guru bidang studi menyebutkan beberapa ayat Alquran dan kemudian dijelaskan di depan kelas maksud dari ayat tersebut sembari menjelaskan korelasi antara materi yang disampaikan dengan ayat Alquran tersebut. Kadang-kadang juga, guru bidang studi memberikan pekerjaan rumah (PR) kepada siswa untuk menghafalkan ayat tersebut di rumah, namun pemberian tugas ini hanya bersifat temporer dan tidak berkelanjutan. 66

Untuk membuktikan kebenaran informasi tersebut di atas, penulis kemudian melakukan observasi dengan cara mengamati langsung kegiatan belajar mengajar bidang studi fisika. Dalam pengamatan tersebut, penulis memang melihat guru bidang studi memasukkan ayat Alquran dalam proses belajar mengajar yang berkaitan dengan materi yang disampaikan, tetapi kegiatan seperti ini dilaksanakan secara sederhana saja, yakni guru membacakan satu ayat Alquran dan siswa mendengarkan bacaan tersebut, kemudian guru menjelaskan ayat Alquran tersebut sepintas dalam hubungannya dengan materi yang disampaikan. Dan pada kesempatan pengamatan tersebut penulis tidak melihat adanya pemberian tugas atau pekerjaan rumah seperti mengahafalkan ayat Alquran yang telah dipelajari sebagaimana informasi yang diperoleh melalui wawancara di atas, namun setelah penulis mengamati secara mendetail, ternyata tugas yang dimaksud di atas diberikan kadang-kadang dan tidak mengikat siswa sebagaimana tugastugas dalam pelajaran yang lain. Dan pada kesempatan pengamatan ini, tugas yang

65 Wakabid Kurikulum SMA Nusantara Adrianus, Wawancara, 8 Juni2013, Jambi, Catatan Lapangan, Kegiatan belajar mengajar yang dilaksanakan guru bidang studi sebagai upaya dalam kegiatan pemberantasan buta aksara Alquran di Sekolah Menengah Atas Nusantara, Jambi.

66 Siwa Kelas X SMA Nusantara Rudi Rolanda, Wawancara, 8 Juni 2013, Jambi, Catatan Penting, Upaya-upaya yang dilakukan dalam mengatasi kendala terkait pemberantasan buta aksara Alquran di Sekolah Menengah Atas Nusantara, Jambi. 
diberikan guru dalam bentuk pekerjaan rumah seperti menghafal beberapa ayat Alquran yang telah dipelajarai tidak diberikan kepada siswa. ${ }^{67}$

Dalam konteks implementasi fungsi-fungsi manajemen yang lain, kepala sekolah belum melaksanakan salah satu fungsi manajamen yang dalam pandangan penulis cukup signifikan dalam rangka mensukseskan program pemberantasan buta aksara Alquran. Fenomena ini tampak pada saat penulis melakukan observasi lanjutan pada kesempatan lain, di mana dalam pengamatan tersebut penulis belum melihat kiat-kiat yang dilakukan kepala sekolah dalam memberikan evaluasi terhadap program-program yang telah dilaksanakan, khususnya program yang berkenaan dengan upaya pemberantasan buta aksara Alquran di Sekolah Menengah Atas Nusantara kota Jambi. Kegiatan tersebut di atas berjalan seiring dengan waktu dan jadwal yang tersedia, padahal evaluasi merupakan salah satu prinsip manajemen yang penting untuk melihat sejauhmana sebuah proses kegiatan berjalan, dan kemungkinan masalah-masalah yang sering dihadapi sebagai suatu kendala manajerial. Di samping itu juga, evaluasi dapat memberikan gambaran tentang kinerja organisasi secara keseluruhan, apakah telah mencapai target dan tujuan organisasi atau belum, sehingga memungkinkan untuk diupayakan berbagai langkah-langkah konstruktif untuk mencapai pengembangan dan peningkatan yang optimal.

Berdasarkan informasi yang diperoleh melalui wawancara dan pengamatan tersebut di atas, dapat penulis simpulkan bahwa kepala sekolah sebagai pimpinan administrasi organisasi Sekolah Menengah Atas Nusantara kota Jambi telah menjalankan perannya sebagai top leader melalui fungsi organizing. Kepala sekolah mengorganisir anggota organisasi, khususnya majelis guru, baik melalui pertemuan resmi ataupun berbentuk pendekatan individu. Namun demikian, kepala sekolah sebagai manajer meninggalkan salah satu fungsi penting manajemen, yaitu fungsi evaluasi. Fungsi ini dalam pandangan beberapa pakar manajemen memiliki korelasi urgen terhadap langkah-langkah organisasi pada fase berikutnya. Hal ini dilandaskan pada pandangan bahwa manajemen adalah sebuah proses dimana seluruh fungsi manajemen diterapkan untuk mencapai tujuan organisasi, sebagaimana diungkapkan Daft dan Steers bahwa manajemen sebagai proses perencanaan, pengorganisasian, dan pengawasan untuk mencapai tujuan yang telah ditetapkan. Adapun Longenecker dan Pringgle mendefinisikan manajemen sebagai proses pengadaan dan pengkombinasian sumber daya manusia, finansial dan fisik untuk mencapati tujuan pokok organisasi”. Adapun Buford an Bedeian menyatakan bahwa manajemen adalah proses untuk mencapai tujuan melalui pemanfaatan sumber daya manusia dan material secara efisien. Dan Joseph L. Massie menjelaskan bahwa manajemen adalah satu satu faktor produksi bersama dengan tanah, tenaga kerja, dan modal. ${ }^{68}$

Dalam kaitannya dengan produktivitas kepala sekolah dalam kerangka manajemen, sangat berkaitan dengan keseluruhan proses perencanaan, penataan dan pendayagunaan sumber daya untuk merealisasikan tujuan pendidikan secara efektif dan efisien yang mencakup tigas fungsi, yaitu fungsi manajerial yang

67 Observasi, 15 Juni 2013 tentang upaya yang dilakukan dalam mengatasi kendala yang dihadapi dalam pemberantasan buta aksara Alquran di Sekolah Menengah Atas Nusantara kota Jambi

68 Syaiful Sagala, Op.Cit., hlm. 51-52 
berkaitan dengan berbagai pelayanan untuk kebutuhan peserta didik dan guru, fungsi behavioral yang keluarannya merujuk pada fungsi pelayanan yang dapat merubah perilaku peserta didik dalam kemampuan kognitif, keterampilan, dan sikap, serta fungsi ekonomi yang keluarannya diidentifikasi sebagai lulusan yang memiliki kompetensi tinggi, sehingga ketika bekerja dapat memperoleh penghasilan tinggi melebihi biaya pendidikan yang telah dikeluarkan. ${ }^{69}$

Adapun kendala yang dihadapi dalam pemberantasan buta aksara Alquran di lingkungan Sekolah Menengah Atas Nusantara kota Jambi terkait dengan minimnya guru PAI di sekolah tersebut, merupakan persoalan yang cukup mendasar yang proses penyelesainnya membutuhkan intervensi beberapa pihak, terutama pihak yayasan yang dalam hal ini merupakan salah unsur penting dalam menentukan kebijakan. Upaya yang paling mudah untuk persoalan keterbatasan minimnya guru PAI, adalah dengan menambah jumlah guru PAI dari satu orang menjadi dua orang atau lebih sesuai dengan kebutuhan sekolah. Namun persoalannya tidaklah semudah yang dihadapi sekolah-sekolah dengan status negeri yang apabila sesuai dengan analisa kebutuhan guru, maka tinggal mengajukan permohonan guru tambahan yang diteruskan ke dinas pendidikan terkait. Maka kemudian dinas terkait melakukan koordinasi dengan beberapa kementerian terkait guna mengajukan kebutuhan guru yang dimaksud. Sekolah Menengah Atas Nusantara kota Jambi yang bernaung di bawah yayasan, di mana kepala sekolah tidak memiliki wewenang mutlak dalam mengambil kebijakan terkait rekrutmen guru baru. Wewenang tersebut menjadi wilayah kajiannya pihak yayasan dengan mempertimbangkan kebutuhan tenaga pengajar dan kemampuan finansial yayasan. Untuk meminimalisir kendala minimnya jumlah guru PAI di sekolah yang dipimpinnya, kepala sekolah hanya mampu berkoordinasi dengan pihak yayasan membicarakan kekurangan guru PAI di sekolah tersebut, adapun keputusan akhir tergantung dari kebijakan yang dikeluarkan pihak yayasan.

Hal senada dikemukakan juga guru PAI Sekolah Menengah Atas Nusantara kota Jambi, yaitu Bapak M. Ridwan, S.Ag dalam kesempatan wawancara dengan penulis bahwa guru PAI di sekolah ini apabila dibandingkan dengan jumlah siswa tidak seimbang, oleh sebab itu perlu ditambah guru PAI satu orang lagi untuk memberikan pembagian jam tatap muka yang seimbang dengan jumlah siswa. Persoalan kurangnya guru PAI di sekolah ini sudah pernah dikomunikasi dengan kepala sekolah, bahkan dalam kesempatan lain pernah berdialog langsung dengan pihak yayasan tentang perlunya penambahan guru PAI. Adapun mekanismenya tergantung dari kebijakan pihak yayasan, apakah dengan mendantangkan guru baru, atau cukup dengan mengangkat satu orang guru dari guru-guru yanga ada di sekolah ini. Namun hingga saat ini, berbatas dengan limit penelitian ini dilakukan, belum mendapatkan tambahan guru PAI di Sekolah Menengah Atas Nusantara kota Jambi. Dan untuk mengantisipasi keterbatasan yang dimiliki guru PAI dalam mengakomodir seluruh siswa-siswi di sekolah, terutama dalam kaitannya dengan pembinaan dan bimbingan baca Alquran, guru PAI menghimbau seluruh siswa untuk memiliki buku saku Juz 'Amma dan selalu dibawa dalam proses belajar mengajar muatan lokal dan materi keagamaan. Dengan buku saku Juz 'Amma tersebut, banyak hal yang dapat dilakukan, seperti menghafal surat-surat pendek

${ }^{69}$ Mukhtar dan Iskandar, Orientasi Suupervisi Pendidikan, (Jakarta: GP Press, 2009), hlm. 161 
Alquran yang secara tidak langsung melatih mereka dalam talfidz dan mendengar. ${ }^{70}$

Untuk membuktikan kebenaran informasi tersebut di atas, penulis melakukan pengamatan di lapangan penelitian. Pengamatan ini berupa pengamatan dokumentasi terkait ada tidaknya guru tambahan yang diberi wewenang mengajar bidang studi PAI di luar guru PAI yang ada. Dalam pengamatan tersebut, penulis memperoleh data bahwa dari dokumentasi dan administrasi sekolah, belum ditemukan guru PAI baru dalam daftar nama-nama guru lengkap dengan materi pelajaran yang diasuh di Sekolah Menengah Atas Nusantara kota Jambi. ${ }^{71}$

Sementara itu, dalam mengatasi kendala yang berkaitan dengan ragamnya latar belakang pendidikan siswa-siswi di Sekolah Menengah Atas Nusantara kota Jambi terkait program pemberantasan buta aksara Alquran, guru bidang studi PAI hanya melakukan pendekatan administratif dengan cara mengklasifikasi kemampuan baca Alquran peserta didik, mulai dari siswa yang memiliki kemampuan baca Alquran yang benar dan fasih sampai pada siswa yang belum mampu membaca Alquran. Data-data yang tertuang dalam daftar klasifikasi kompetensi baca Alquran siswa dijadikan pedoman guru bidang studi dalam memberikan pembinaan dan bimbingan yang integratif dalam bidang studi agama Islam. Siswa-siswi yang belum mampu membaca Alquran dengan baik dan sempurna diupayakan diberikan bimbingan lebih dibandingkan siswa lain yang telah mampu membaca Alquran meskipun belum sempurnan dengan terapan ilmu tajwid yang baik pula. Ketika hal ini dikonfirmasikan dengan guru PAI Sekolah Menengah Atas Nusantara kota Jambi melalui sebuah wawancara, beliau mengatakan bahwa dalam penanganan siswa-siswi yang memiliki keragaman latar belakang pendidikan, dilakukan klasifikasi kompetensi masing-masing siswa dengan cara mengelompokkan mereka dalam proses belajar mengajar Alquran yang terintegrasi dalam bidang studi agama Islam. Tidak ada pemberian materi khusus bagi mereka yang kurang mampu membaca Alquran dengan baik, mereka hanya diberikan kesempatan yang lebih besar dibandingkan siswa-siswi yang sudah mampu lainnya. Misalnya ketika materi pelajaran berkaitan dengan sejarah turunnya Alquran, maka surat yang dijadikan objek pembelajaran adalah surat al 'Alaq. Dalam proses latihan membaca, siswa-siswi yang kurang mampu membaca Alquran diberikan kesempatan membaca hingga dua kali, baru kemudian beralih kepada siswa yang sudah memiliki kemampuan dasar membaca Alquran. ${ }^{72}$

Untuk mendapatkan informasi yang lebih akurat terkait informasi yang diperoleh sebelumnya, penulis melakukan observasi di lapangan penelitian. Observasi ini dilaksanakan untuk melihat secara langsung bagaimana langkahlangkah yang dilakukan guru PAI dalam mengatasi keragaman kemampuan baca Alquran peserta didik disebabkan perbedaan latar belakang pendidikan mereka.

70 Guru PAI SMA Nusantara M. Ridwan, Wawancara, 13 Juni 2013, Jambi, Catatan Lapangan, Upaya-upaya yang dilakukan dalam mengatasi kendala kekurang guru PAI di Sekolah Menengah Atas Nusantara, Jambi.

${ }^{71}$ Observasi, 15 Juni 2013 tentang ada tidaknya guru tambahan baru yang mengasuh bidang studi PAI di Sekolah Menengah Atas Nusantara kota Jambi

72 Guru PAI SMA Nusantara M. Ridwan, Wawancara, 16 Juni 2013, Jambi, Catatan Lapangan, Upaya yang dilakukan dalam mengatasi kendala terkait perbedaan latar belakang pendidik di Sekolah Menengah Atas Nusantara, Jambi. 
Dalam pengamatan tersebut, penulis mendapat suasana kelas terbagi tiga kelompok, dari kelompok yang sudah mahir, setengah mahir dan belum mahir membaca Alquran. Meskipun kesempatan yang diberikan kepada siswa yang belum mahir membaca Alquran lebih besar dibanding kelompok lain, tetapi tampaknya belum mampu mengakomodir seluruh siswa dalam ruang belajar. Sehingga masih terdapat siswa yang belum mendapatkan kesempatan membaca Alquran disebabkan terbatasnya waktu tatap muka. ${ }^{73}$

Adapun upaya mengatasi kendala rendahnya partisipasi aktif para orang tua wali murid dalam kegiatan pemberantasan buta aksara Alquran di Sekolah Menengah Atas Nusantara kota Jambi hanya bersifat anjuran dan dorongan moril. Meskipun dorongan moril tersebut belum menyentuh esensi pemberantasan buta aksara Alquran, tetapi secara emosional telah memberikan gambaran kepada orang tua wali murid tentang kemampuan dasar baca Alquran yang dimiliki anakanak mereka, sehingga mereka tergugah untuk memberikan pengayaan terhadap anak-anak mereka di rumah. Dan ketika informasi di atas dikomunikasikan dengan guru PAI, beliau menjelaskan bahwa tidak dilakukannya penegasan kepada para orang tua wali murid terkait kemampuan baca Alquran anak-anak mereka, lebih disebabkan karena pada saat penerimaan siswa baru kemampuan baca Alquran tidak termasuk syarat yang harus dipenuhi oleh siswa. Oleh karena itu, dalam rapat wali murid kepala sekolah hanya menyinggung lemahnya kemampuan dasar baca Alquran siswa-siswi di Sekolah Menengah Atas Nusantara kota Jambi. Dan untuk menutupi kelemahan tersebut, kepala sekolah menganjurkan para orang tua wali murid untuk membimbing kembali putra-putri mereka di rumah dalam belajar membaca Alquran dan atau mendatangkan guru pembimbing khusus (guru ngaji) sebagaimana telah dikemukakan pada pembahasan sebelumnya. ${ }^{74}$

Untuk melihat kebenaran informasi tersebut, penulis berupaya menggali informasi lain dengan cara ikut serta dalam rapat orang tua wali murid pada saat penerimaan raport semester genap. Informasi yang dapat penulis himpun dari pertemuan tersebut menunjukkan bahwa kepala sekolah yang memimpin rapat mengajak seluruh orang wali murid untuk aktif membimbing anak-anak mereka membaca Alquran di rumah, terutama anak-anak yang belum mampu membaca Alquran dengan baik. Ajakan ini disampaikan karena masih banyaknya siswa-siswi di Sekolah Menengah Atas Nusantara kota Jambi yang belum bisa membaca Alquran dengan baik sesuai hukum tajwid yang ada. ${ }^{75}$

\section{Kesimpulan}

Berdasarkan hasil analisa sebagaimana telah dipaparkan pada pembahasan sebelumnya, maka pada bagian ini akan dikemukakan beberapa rumusan sebagai

73 Observasi, 24 Mei 2013 tentang upaya penanganan siswa-siswi yang memiliki latar belakang pendidikan berbeda dan berimplikasi pada perbedaan kemampuan baca Alquran yang dilakukan guru PAI di Sekolah Menengah Atas Nusantara kota Jambi

${ }^{74}$ Guru PAI SMA Nusantara M. Ridwan, Wawancara, 29 Juni 2013, Jambi, Catatan Lapangan, Upaya yang dilakukan dalam mengatasi kendala rendahnya partisipasi orang tua wali murid dalam kegiatan pemberantasan buta aksara Alquran di Sekolah Menengah Atas Nusantar, Jambi.

75 Observasi, 29 Juni 2013 tentang upaya yang dilakukan dalam memotivasi orang tua wali murid agar selalu membimbing anak-anak mereka di rumah dalam rangka pemberantasan buta aksara Alquran di Sekolah Menengah Atas Nusantara kota Jambi 
kesimpulan akhir dan sekaligus sebagai jawaban atas pertanyaan-pertanyaan dalam rumusan masalah. Kesimpulan penelitian ini secara konkrit adalah: pertaman, bentuk manajemen yang dipraktikkan kepala sekolah dalam kegiatan pemberantasan buta aksara Alquran di Sekolah Menengah Atas Nusantara kota Jambi adalah manajemen partisipatif dengan gaya kepemimpinan demokratis. Kedua, Kepala Sekolah sebagai pimpinan lembaga, dalam memaksimalkan peran Guru PAI dalam rangka pemberantasan buta aksara Alquran menerapkan fungsifungsi manajemen seperti planning, organizing, actuating, controlling. Akan tetapi belum memaksimalkan fungsi evaluating sebagai salah satu tolok ukur menilai keberhasilan kegiatan pemberantasan buta aksara Alquran. Ketiga, adapun kendala yang dihadapi dalam kt 167 pemberantasan buta aksara Alquran di Sekolah Menengah Atas Nusantara кота Jambi mencakup beberapa hal, yaitu: kurikulum terapan Diknas Pendidikan yang belum memberikan ruang penuh dan formal terhadap pelaksanaan pemberantasan buta aksara Alquran, minimnya jumlah guru PAI, latar belakang pendidikan siswa yang berbeda, dan kurangnya partisipasi para orang tua wali murid terhadap program tersebut di atas. Keempat, upaya-upaya yang dilakukan kepala sekolah dalam mengatasi kendala tersebut di atas adalah melakukan pendekatan kepada majelis guru, mengusulkan kepada pihak yayasan untuk menambah guru PAI, menginstruksikan guru PAI melakukan klasifikasi dan pengelompokan dengan memprioritaskan kelompok yang belum mampu membaca Alquran dengan baik, dan mendorong para orang tua/wali murid secara moril untuk meningkatkan peran serta dalam memberikan bimbingan baca Alquran terhadap anak-anak mereka di rumah.

\section{BIBLIOGRAFI}

A.A. Anwar Prabu Mangkunegara, Evaluasi Kinerja SDM, (Bandung: PT. Refika Aditama, 2010).

Fred R. David, Terj., Manajemen Strategis: Konsep, (Jakarta: Salemba Empatm 2006).

Hasan Basri Agus, "Pemberantasan Buta Aksara Alquran”, Harian Pagi Tiribun, Agustus 7, 2012,

J.A.F. Stoneer, terj., Perencanaan dan Pengambilan Keputusan, (Jakarta: Erlangga, 1992), hlm. 9

Sa'dulloh, Metode Qur'any: Belajar Baca Alquran Untuk Semua Umur, (Yogyakarta: Mutiara Media, 2010).

Muhammad Ali Ash Shaabuniy, Terj., Studi Ilmu Alquran, (Bandung: CV. Pustaka Setia, 2008).

Zakiah Daradjat, Metodik Khusus Pengajaran Agama Islam, (Jakarta: Bumi Aksara, 2008). 